\title{
Pathobiology and management of prostate cancer-induced bone pain: recent insights and future treatments
}

\author{
Arjun Muralidharan $\cdot$ Maree T. Smith
}

Received: 31 March 2013/Accepted: 23 July 2013/Published online: 6 August 2013

(c) The Author(s) 2013. This article is published with open access at Springerlink.com

\begin{abstract}
Prostate cancer (PCa) has a high propensity for metastasis to bone. Despite the availability of multiple treatment options for relief of PCa-induced bone pain (PCIBP), satisfactory relief of intractable pain in patients with advanced bony metastases is challenging for the clinicians because currently available analgesic drugs are often limited by poor efficacy and/or dose-limiting side effects. Rodent models developed in the past decade show that the pathobiology of PCIBP comprises elements of inflammatory, neuropathic and ischemic pain arising from ectopic sprouting and sensitization of sensory nerve fibres within PCa-invaded bones. In addition, at the cellular level, PCIBP is underpinned by dynamic cross talk between metastatic PCa cells, cellular components of the bone matrix, factors associated with the bone microenvironment as well as peripheral components of the somatosensory system. These insights are aligned with the clinical management of PCIBP involving use of a multimodal treatment approach comprising analgesic agents (opioids, NSAIDs), radiotherapy, radioisotopes, cancer chemotherapy agents and bisphosphonates. However, a major drawback of most rodent models of PCIBP is their short-term applicability due to ethical concerns. Thus, it has been difficult to gain insight into the mal(adaptive) neuroplastic changes
\end{abstract}

A. Muralidharan · M. T. Smith ( $\square)$

Centre for Integrated Preclinical Drug Development,

The University of Queensland, Level 3, Steele Building,

St Lucia Campus, Brisbane, QLD 4072, Australia

e-mail: maree.smith@uq.edu.au

A. Muralidharan - M. T. Smith

The School of Pharmacy, The University of Queensland, Level

3, Steele Building, St Lucia Campus, Brisbane, QLD 4072,

Australia occurring at multiple levels of the somatosensory system that likely contribute to intractable pain at the advanced stages of metastatic disease. Specifically, the functional responsiveness of noxious circuitry as well as the neurochemical signature of a broad array of pro-hyperalgesic mediators in the dorsal root ganglia and spinal cord of rodent models of PCIBP is relatively poorly characterized. Hence, recent work from our laboratory to develop a protocol for an optimized rat model of PCIBP will enable these knowledge gaps to be addressed as well as identification of novel targets for drug discovery programs aimed at producing new analgesics for the improved relief of intractable PCIBP.

Keywords Bone pain - Prostate cancer - Analgesics . Bone metastases

\section{Introduction}

Prostate cancer (PCa) is the second most common form of cancer affecting men worldwide (Ferlay et al. 2010) and a typical feature is its ability to metastasize to bone. Although metastatic cancer cells may theoretically invade any organ of the body, postmortem examination reveals that $\sim 70 \%$ of patients with metastatic prostate carcinomas have a high incidence of bone lesions (Coleman 2006). Metastatic bone disease in advanced-stage PCa increases the risk of intractable cancer-induced bone pain, pathological skeletal fracture, spinal-cord compression, decreased survival and poor quality of life (Coleman 2006). If $\mathrm{PCa}$ is detected and treated at an early stage, the 5-year survival rate is $100 \%$ whereas if the initial diagnosis is of advanced metastatic disease, the 5-year survival rate is only $33 \%$ (Jemal et al. 2007). 
Following metastatic spread of PCa to the skeleton, patients report that persistent prostate cancer-induced bone pain (PCIBP) is one of the most distressing symptoms (Mantyh 2006). Pharmacological management of PCIBP involves use of analgesic agents such as non-steroidal antiinflammatory drugs (NSAIDs) and opioid analgesics in combination with adjuvant therapies including bisphosphonates, corticosteroids, chemotherapy agents, radiotherapy and radionucleotides (Mercadante and Fulfaro 2007). According to the three-step 'Analgesic Ladder' first published by the World Health Organisation (WHO) in 1986, cancer pain should be managed according to its intensity (WHO 1986). For mild pain (Step 1), non-opioid analgesics such as NSAIDs are recommended with addition of adjuvant drugs such as anti-convulsants or tricyclic antidepressants if there is a neuropathic component. For moderate pain (Step 2), weak opioid analgesics such as tramadol or codeine are added. For patients with moderate to severe pain (Step 3), strong opioid analgesics such as morphine are recommended together with non-opioid analgesics and adjuvant drugs if there is a neuropathic component. As NSAIDS, opioid analgesics and many adjuvants often have unacceptable side effects that may be dose limiting (IASP 2009), there is a large unmet medical need for a new generation of highly effective, well-tolerated novel analgesics/ adjuvants for improved relief of PCIBP.

\section{Normal bone physiology}

Two vital functions of the skeleton are calcium homeostasis and mechanical support. The structural integrity of a healthy bone is maintained by a process of perpetual remodelling (Clarke 2008) encompassing removal of discrete parts of an old bone, replacement with newly synthesized proteinaceous matrix and subsequent mineralization of the matrix to form new bone (Fig. 1) (Proff and Romer 2009). The bone remodelling unit comprises a tightly coupled group of osteoclasts and osteoblasts that sequentially carry out balanced resorption and formation of bone (Saylor and Smith 2010) to prevent accumulation of bone microdamage (Proff and Romer 2009).

Osteoclasts and osteoblasts

Osteoclasts are the only cells that are known to resorb bone. Activated multinucleated osteoclasts are derived from mononuclear precursor cells of the monocyte macrophage lineage (Takahashi et al. 2002). On the other hand, osteoblasts are bone-forming cells that arise from mesenchymal stem cells that also give rise to adipocytes and muscle cells (Aubin 1998).

Osteoblasts and stromal cells produce receptor activator of NF- $\kappa \mathrm{B}$ ligand (RANKL), a member of the TNF superfamily of cytokines, that interacts with the receptor activator of nuclear factor- $\kappa \mathrm{B}$ (RANK) (Lacey et al. 1998) expressed on pre-osteoclasts to induce their maturation into multinucleated osteoclasts (Dougall et al. 1999). Macrophage colony-stimulating factor (M-CSF) is required for the proliferation, survival, and differentiation of osteoclast precursors, as well as osteoclast survival and the cytoskeletal rearrangement required for bone resorption (Hattersley et al. 1991). A transcription factor that is critical for the differentiation of osteoblasts is Runt-related transcription factor 2 (Runx-2), or core-binding factor $\alpha 1$ (CBFA1) (Pratap et al. 2011). Many other factors such as platelet-derived growth factor (PDGF), fibroblast growth factor (FGF), and transforming growth factor- $\beta$ (TGF- $\beta$ ) can also enhance the growth and differentiation of osteoblasts (Mundy et al. 2001).

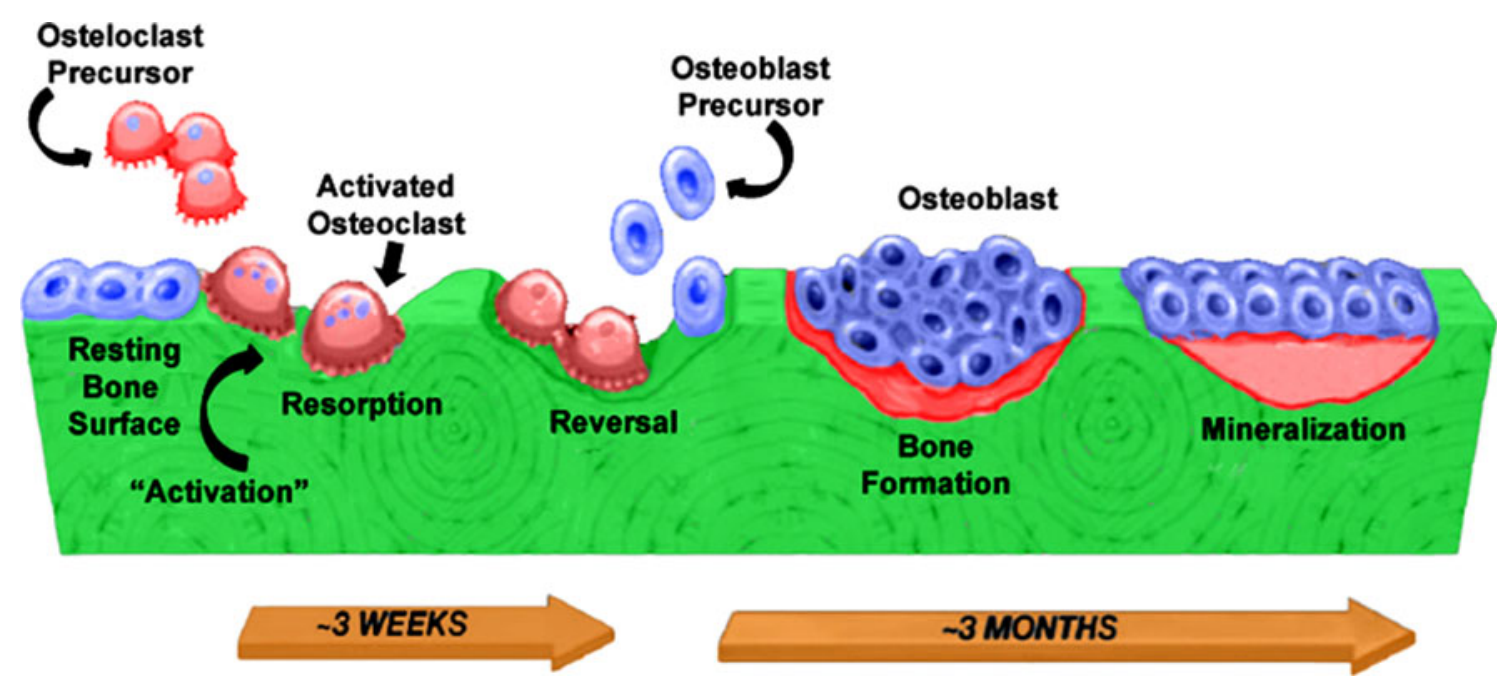

Fig. 1 Normal bone remodelling process [adapted from Lipton (2010)] 
Bone, a preferred site for metastases

Factors contributing to the predilection of $\mathrm{PCa}$ metastasis to bone include higher blood flow in the areas of red marrow, and the fact that tumour cells produce adhesion molecules such as $\alpha 4 \beta 1, \alpha 5 \beta 1, \alpha v \beta 3, \alpha v \beta 5$ that facilitate binding to marrow stromal cells and bone matrix (Lee et al. 2011). Increased production of angiogenic factors and bone-resorbing factors further enhance tumour growth in bone (van der Pluijm et al. 2001). The physical properties of the bone matrix, including low oxygen, acidic $\mathrm{pH}$, high extracellular $\mathrm{Ca}^{2+}$ concentration (Morrissey and Vessella 2007) and growth factors such as TGF- $\beta$, insulin-like growth factors (IGF) I and II, FGF, PDGF, bone morphogenetic proteins (BMPs) (Bussard et al. 2008), which are released and activated during bone remodelling provide fertile ground for growth of the tumour cell.

\section{Rodent models of PCIBP}

Rodent models of PCIBP involving intra-osseous injection of PCa cells with subsequent temporal development of hypersensitivity (pain) behaviours (Table 1) have been invaluable for generation of knowledge on the pathobiology of PCIBP and for the screening of novel molecules as potential analgesics/adjuvant agents for improved relief of this condition.

However, a major limitation of many currently utilized rodent models of PCIBP (Table 1) is that they involve intra-osseous injection of very large numbers of PCa cells which results in profound bone destruction (Lamoureux et al. 2008; De Ciantis et al. 2010; Kolosov et al. 2011; Feeley et al. 2006; Liepe et al. 2005; Zhang et al. 2005). This facilitates PCa cell metastasis formation in the adjacent soft tissues as well as the lungs and liver (Kolosov et al. 2011; Liepe et al. 2005; Luo et al. 2006). The net result is the progressive deterioration of animal health, characterized by a significant temporal decrease in body weight relative to the sham-control groups (Zhang et al. 2005; De Ciantis et al. 2010), necessitating early euthanasia due to ethical concerns.

To address this issue, our laboratory has successfully established and characterized a rat model of PCIBP involving unilateral intra-tibial injection (ITI) of the optimal number of AT3B PCa cells to produce osteosclerotic tumours confined to the injected tibial bones whilst maintaining good general animal health for at least a 90-day post-ITI period (Muralidharan et al. 2013). Although there appeared to be spontaneous resolution of hindpaw hypersensitivity between days 21 and 90 post-ITI, we further showed that the underlying pain phenotype could be unmasked by administration of the prototypic opioid receptor antagonist, naloxone, at days 28-37 and 85-90 post-ITI (Muralidharan et al. 2013). Hence, our work using the aforementioned optimized rat model of PCIBP implicates a role for upregulated endogenous opioidergic signalling in masking pain associated with advanced PCainduced bony metastases (Muralidharan et al. 2013). Importantly, our findings may explain at least in part why pain symptoms are often hidden in patients with metastatic PCa bone tumours until the later stages of metastatic disease as well as why it is often difficult for the clinicians to correlate the degree of pain reported with the functional ability of patients with disseminated PCa-induced metastases of the skeleton (Clare et al. 2005).

Mechanisms of PCa metastasis to the bone

Skeletal metastases are radiographically classified as osteosclerotic or osteolytic (Kingsley et al. 2007). These lesions result from an imbalance between osteoblast-mediated bone formation and osteoclast-mediated bone resorption (Chirgwin and Guise 2007). The lesion is called osteosclerotic when bone formation overcomes bone resorption, or osteolytic when a decrease in bone density occurs via increased bone resorption (Kakonen and Mundy 2003). Osteolytic and osteosclerotic metastases are characteristic of breast and prostate cancer, respectively. Approximately $80 \%$ of patients with stage IV metastatic breast cancer have osteolytic lesions (Kozlow and Guise 2005) whereas $91 \%$ of bone metastases from prostate cancer have osteosclerotic features on plain radiography (Berruti et al. 1999). However, histology shows that the majority of PCa-induced bone metastases in patients are phenotypically heterogeneous within and between lesions although predominantly osteosclerotic (Msaouel et al. 2008).

Metastatic process: tumour dissemination to establishment

Bone metastasis is complex and begins with tropism of cells to invasion and proliferation (Fig. 2). Briefly, cancer cells detach from the primary tumour and migrate locally to invade blood vessels and the lymphatic system (intravasation). Once in the bloodstream, cancer cells are attracted to preferred sites of metastasis through site-specific interactions between tumour cells and cells in the target tissue (Weilbaecher et al. 2011).

Several groups have demonstrated the importance of the chemokine CXCL12 [also known as stromal cell-derived factor $1(\mathrm{SDF}-1)$ ] and its receptor $\mathrm{CXCR} 4$ in $\mathrm{PCa}$ cell proliferation in vivo (Zhang et al. 2008b; Sun et al. 2003) and in vitro (Taichman et al. 2002; Hirbe et al. 2010). The binding of CXCL12 to CXCR4 initiates divergent downstream signalling pathways, which in turn modulate 







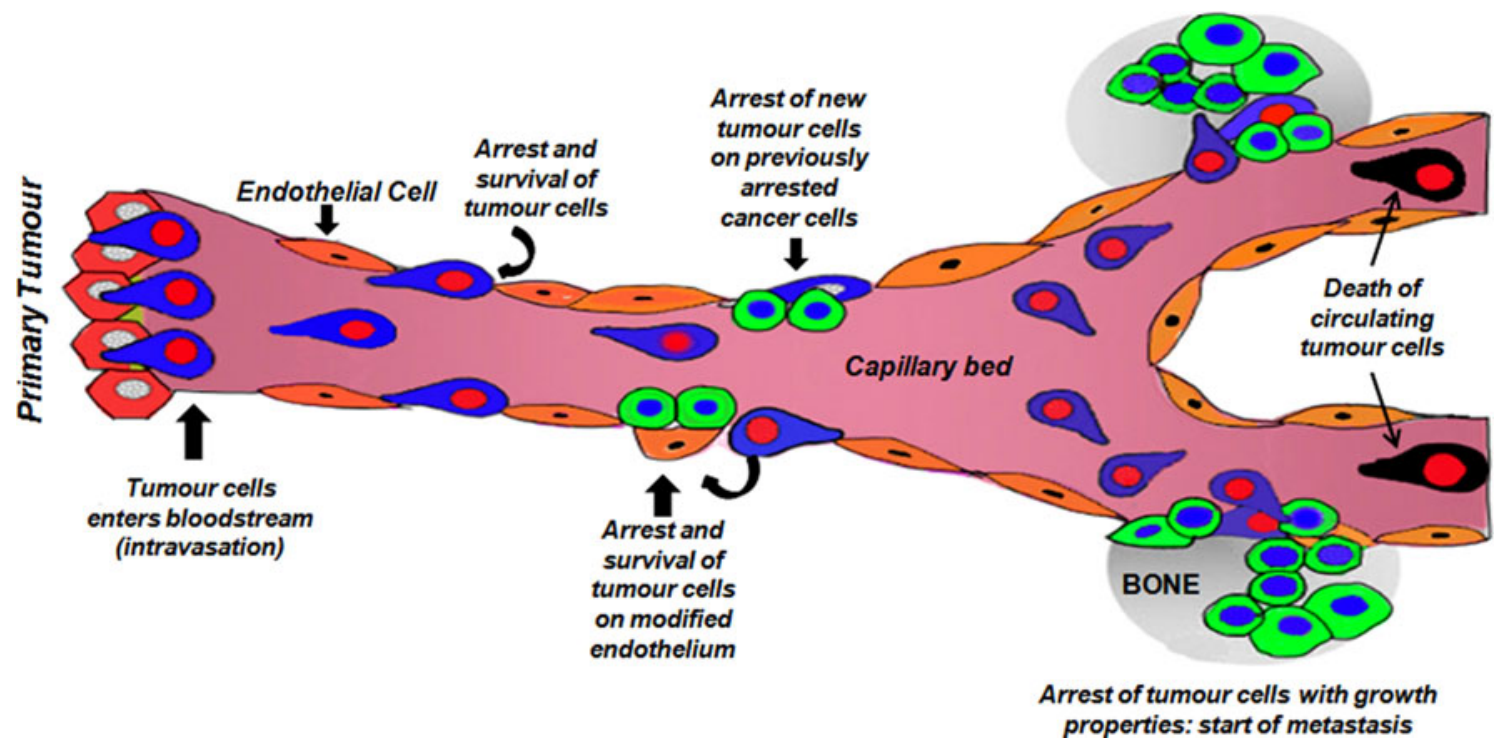

Fig. 2 Metastatic process: tumour dissemination to establishment [adapted from Bidard et al. (2008)]

multiple aspects of tumour progression including angiogenesis, chemotaxis, cell survival and/or proliferation (Teicher and Fricker 2010). One hypothesis is that osteoblasts express the chemokine CXCL12 as well as other cytokines and growth factors including interleukin (IL)-1 $\beta$, PDGF, vascular endothelial growth factor (VEGF) and tumour necrosis factor (TNF)- $\alpha$ that act on osteoblasts to increase CXCL12 expression levels (Jung et al. 2006). In support of this notion, at least 23 different types of cancer cells including PCa cells express CXCR4 (Balkwill 2004) and once in the bloodstream, PCa cells migrate down the chemotactic gradient to bone (Sun et al. 2005). In other work, the monocyte chemotactic protein-1 (MCP-1)/CCR2 axis has also been implicated in the tropism of PCa cells towards bone (Lu et al. 2009).

Following intravasation, cancer cells have to survive the mechanical stress of vascular transportation as well as the host's immune defences. To survive the mechanical stress of transport in the bloodstream, cancer cells circulate as part of a fibrin clot (Walz and Fenton 1994) and to evade the immune system, there is downregulation of the expression of major histocompatibility complex (MHC) class I (Wu et al. 2004). Tumour cells that survive these hurdles adhere to the endosteal surface of bone, for which the success rate is as low as $0.1 \%$ for each circulating cell (Luzzi et al. 1998). Factors implicated in cell adhesion and migration of PCa cells include E-selectin and sialylated glycoconjugates, vascular cell adhesion molecule-1 (VCAM-1), $\alpha_{v} \beta_{3}, \alpha_{2} \beta_{1}, \alpha_{4} \beta_{6}$ and $\alpha_{4} \beta_{1}$ integrins, cadherin11 as well as extracellular matrix proteins (osteonectin, osteopontin, osteocalcin, bone sialoprotein and fibronectin) and the CXCL13-CXCR5 axis (Jin et al. 2011). The invading cells acquire 'bone-cell'-like properties or 'osteomimicry' and produce transcription factors such as Runx2 (Pratap et al. 2011) and Homeo box homolog 2 (MSX-2) (Barnes et al. 2003) that increase the expression of osteopontin (Desai et al. 2007), osteocalcin (Huang et al. 2005), osteonectin (Campo McKnight et al. 2006) and bone sialoprotein II (Adwan et al. 2004).

Transition: orchestration by osteoclasts domination by osteoblasts

Orchestration by osteoclasts Unlike other metastatic tumours in bone that are characterized by an ongoing vicious osteolytic cycle, $\mathrm{PCa}$ cells initially display osteolytic activity that eventually transforms to the predominant osteosclerotic phenotype (Msaouel et al. 2008). Hence, for patients with PCa-induced bony metastases, markers of both bone resorption [urinary N-telopeptide (uNTX), C-telopeptide type I collagen, pyridinoline cross-linked peptide and deoxypyridinoline cross-linked peptide] and bone formation [osteocalcin and bone-specific alkaline phosphatase (BAP), prostate-specific antigen (PSA), tartrate-resistant acid phosphatase (TRAP)] are high (Leeming et al. 2008; Seibel 2008; Saad and Lipton 2010a).

On plain radiography, $\mathrm{PCa}$ metastasis results in increased abnormal bone formation with an often elevated osteoid surface area and volume (Ibrahim et al. 2010). The osteolytic-osteogenic bone lesions are responsible for the abnormal bone formation and fractures at later stages (Ye et al. 2007). The initial osteolytic phase in PCa metastases helps in debulking the bone, thereby promoting seeding of cancer cells and production of growth factors (Msaouel et al. 2008). Several osteoclastogenic factors have been implicated in the increased activity of osteoclasts 

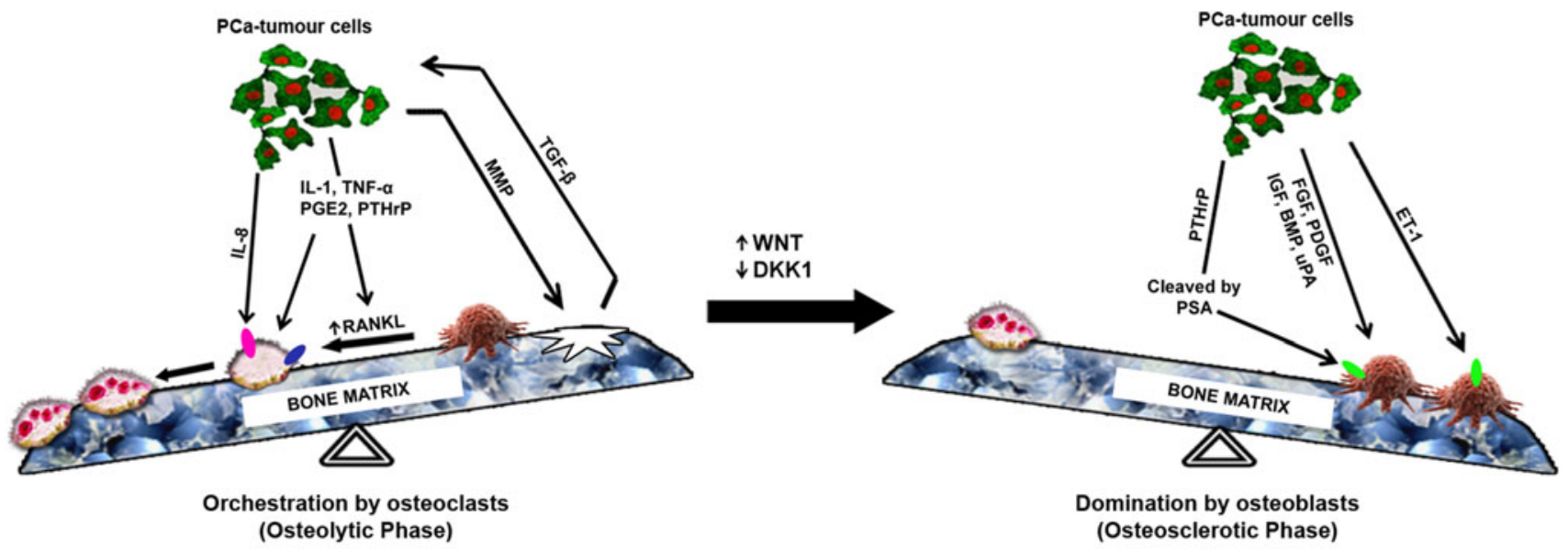

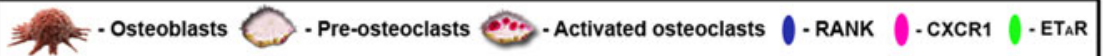

Fig. 3 Schematic representation of the phases of phenotypic transition: orchestration by osteoclasts to domination by osteoblasts [adapted from Clines and Guise (2008)]. Wnt wingless-type protein, $D K K-1$ dickkopf homologue $1, P C a$ prostate cancer, $T G F-\beta$ transforming growth factor- $\beta, M M P$ matrix metalloproteinases, TNF $\alpha$ tumour necrosis factor- $\alpha, I L$ interleukin, $P G E_{2}$ prostaglandin $\mathrm{E}_{2}$,

(Roodman 2001) including IL-1, IL-6, IL-8, IL-11, macrophage inflammatory protein $1 \alpha$ (MIP-1 $\alpha$ ), TNF- $\alpha$, RANKL, parathyroid hormone-related protein (PTHrP) and prostaglandin E2 (PGE2) (Zhang et al. 2010; Casimiro et al. 2009; Bussard et al. 2008) (Fig. 3). Of interest, many of these factors are pro-inflammatory and are implicated in the pathobiology of multiple chronic pain states (see "Metastasis or tumourigenesis inhibitors" for further discussion).

Osteoprotegerin (OPG), a natural decoy receptor for RANKL, acts as a negative regulator of the RANK/RANKL pathway by sequestering RANKL (Lipton and Goessl 2011). Though several other hormones and cytokines may play a role, only RANKL is absolutely required for osteoclastogenesis ( $\mathrm{Li}$ et al. 2000). PCa cells express RANK/ RANKL and the levels of RANKL/OPG are elevated in patients with PCa-induced bone metastases (Chen et al. 2006). OPG also serves as a survival factor by inhibiting the apoptosis of PCa cells induced by the TNF-related apoptosis-inducing ligand (TRAIL) (Holen et al. 2002).

Apart from direct stimulation of osteoclast precursors, IL1 , TNF- $\alpha$, PGE2 and PTHrP contribute to osteoclastogenesis by upregulating the production of RANKL by osteoblasts (Kwan Tat et al. 2004). In addition, TGF- $\beta$ released as a result of bone matrix degradation by matrix metalloproteinases (MMPs) stimulates PTHrP, thereby creating a positive feedback loop (Guise and Chirgwin 2003). IL-8 stimulates osteoclastogenesis via increasing RANKL production by binding to the chemokine receptor, CXCR1, on osteoclast precursor cells (Bendre et al. 2003). This in turn increases PGE2 (Kundu et al. 2001) and suppresses
$R A N K L$ receptor activator of NF- $\mathrm{KB}$ ligand, $R A N K$ receptor activator of NF-кB, $P T H r P$ parathyroid hormone-related protein, $F G F$ fibroblast growth factor, $B M P$ bone morphogenetic protein, $P D G F$ platelet-derived growth factor, IGF insulin-like growth factor, ET-1 endothelin-1, $u P A$ urokinase-type plasminogen activator, PSA prostate-specific antigen

osteoblast activity (Dovio et al. 2004). MIP-1 $\alpha$ is a potent inducer of osteoclast formation in vitro in a manner independent of RANKL that enhances both RANKL-stimulated and IL-6-stimulated osteoclast formation (Han et al. 2001).

Domination by osteoblasts Metastasis factors such as wingless-type protein (Wnt)-1, IGF-I, BMPs, basic fibroblast growth factor (bFGF), IL-6, endothelin (ET)-1 and PTHrP dominate by stimulating osteoblast activity through autocrine and paracrine activity (Ibrahim et al. 2010). The Wnt pathway/ET axis/BMP pathway has emerged as a key regulator of osteosclerotic metastasis (Robinson et al. 2008; Sethi and Kang 2011) (Fig. 3).

Wnt proteins are soluble glycoproteins that bind to frizzled $G$ protein-coupled receptors and low-density lipoprotein receptor-related protein (Bodine and Komm 2006). Wnt signalling is a key osteoblast regulatory pathway critical for osteoblast differentiation and function (Bodine and Komm 2006; Sethi and Kang 2011). Dickkopf homologue $1(\mathrm{DKK}-1)$ is a protein that regulates PCa bone metastasis progression by opposing the actions of osteogenic Wnts early on, thereby controlling the phenotypic switch from osteolytic to osteosclerotic lesions (Hall et al. 2008). Indeed, levels of DKK-1 are elevated in early events associated with PCa but levels decrease with disease progression, thereby increasing osteosclerotic activity in advanced metastases (Hall et al. 2008).

ET-1 is implicated as a central mediator of osteosclerotic metastasis (Mohammad and Guise 2003) as it stimulates the formation of bone and the proliferation of 
osteoblasts that express the endothelin A receptor $\left(\mathrm{ET}_{\mathrm{A}} \mathrm{R}\right)$ (Kasperk et al. 1997). Levels of alkaline phosphatase, a bone formation marker, are elevated in patients with osteosclerotic PCa cell-induced bone metastases (Nelson et al. 1995). Although PTHrP is an osteolytic factor, it is highly expressed even in the later stages of PCa. An explanation for this somewhat paradoxical observation is that the $\mathrm{NH}_{2}$-terminal fragments of PTHrP that are cleaved by PSA (Cramer et al. 1996) share high sequence homology with ET-1 and therefore likely activate the $\mathrm{ET}_{\mathrm{A}} \mathrm{R}$ (Schluter et al. 2001). ET-1 is thought to activate the Wnt signalling pathway by reducing paracrine production of the Wnt antagonist, DKK-1 (Clines et al. 2007).

Other factors including PDGF (Yi et al. 2002), urokinase-type plasminogen activator (uPA) (Achbarou et al. 1994), PSA (Cramer et al. 1996), IGF-binding proteins (IGFBP) and BMP-2/6/7 also play a significant role (Casimiro et al. 2009). The overproduction of uPA by prostate cancer cells increases the severity of bone metastasis (Achbarou et al. 1994). Prostate cancer cells also release PSA, a kallikrein serine protease. In addition to cleaving PTHrP, PSA also cleaves IGFBP-3, thereby paving the way for IGF-1 to bind to its receptor and to stimulate osteoblast proliferation (Cohen et al. 1994). Thus, there are many tumour-produced factors that impact osteoclasts, osteoblasts, the tumour itself and the bone microenvironment in a vicious cycle to promote the development and progression of bone metastasis (Buijs et al. 2007).

\section{Pathophysiology of PCIBP}

\section{Nociceptive signalling and pain}

Pain severity reports by patients comprise an integration of nociception overlaid by emotional interpretation by higher centres in the brain (Rainville et al. 1997). Briefly, nociception involves detection of potentially damaging stimuli by free nerve endings (nociceptors) in the periphery to generate action potentials that are transmitted by primary afferent sensory nerve fibres to laminae I and II of the dorsal horn of the spinal cord (Sherrington 1906). Transmission of these nociceptive signals by second-order neurons via the spinothalamic tracts to higher centres in the brain may in turn activate endogenous descending opioidergic and noradrenergic signalling pathways to reduce pain severity (see reviews by Smith and Muralidharan 2013; Basbaum et al. 2009). In chronic inflammatory and peripheral neuropathic pain states, peripheral nociceptors become sensitized resulting in ectopic firing and induction of neuroplastic changes in the spinal cord and supraspinally; this has been reviewed in detail elsewhere (see Smith and Muralidharan 2013; Basbaum et al. 2009).
In the following sections of our review herein, we discuss the mechanisms underpinning sensitization of peripheral nerve fibres and the development of so-called 'central sensitization' in the context of the development and maintenance of PCIBP.

\section{Peripheral sensitization mechanisms in PCIBP}

In patients with advanced bony metastases, intermittent episodes of extreme pain, known as breakthrough pain, may occur spontaneously as a result of bone remodelling (Mercadante 1997) or be induced by movement of tumourbearing bone (Mercadante and Arcuri 1998). The various compartments of the bone, viz. bone marrow, mineralized bone and the periosteum, are densely innervated by both sensory and/or sympathetic nerve fibres (Jimenez-Andrade et al. 2010b). Thus, tumours invading and proliferating within the medullary space of the bone sensitize primary afferent nerve fibres and induce pronounced infiltration of inflammatory cells. The periosteum is innervated by a mesh of calcitonin gene-related peptide (CGRP) and substance $\mathrm{P}$ (Sub P)-expressing sensory nerve fibres that are implicated in movement-related pain (Martin et al. 2007).

The broad array of pro-hyperalgesic mediators released by osteoclasts, osteoblasts, tumour and tumour-associated immune cells (macrophages, neutrophils and $\mathrm{T}$ cells) outlined in the preceding section ("Transition: orchestration by osteoclasts domination by osteoblasts") collectively sensitize peripheral nociceptors in the bone milieu to subsequent nociceptive stimuli and/or directly activate specific receptors located on the primary afferents themselves (Jimenez-Andrade et al. 2010b). Thus, prostaglandins, endothelins, bradykinin, colony-stimulating factors, TNF$\alpha$, TGF- $\beta$, PDGF, IL-1, nerve growth factor (NGF) and IL6 are components of a 'pro-inflammatory soup' that sensitize nociceptors in prostate cancer-induced bone pain (Fig. 4) (Mantyh 2006; Schmidt et al. 2010). In addition, osteoclast- and tumour-induced acidosis in bone tissue may also contribute to the pathobiology of PCIBP by sensitizing subsets of sensory neurons that express the transient receptor potential vanilloid 1 (TRPV1) (Caterina et al. 2000) and/or the acid-sensing ion channel 3 (ASIC3) (Olson et al. 1998).

Following injection of PCa cells into the mouse femur, profound pathological sprouting of $\mathrm{CGRP}^{+}$and neurofilament $200 \mathrm{kDa}(\mathrm{NF} 200)^{+}$sensory nerve fibres and tyrosine hydroxylase-positive post-ganglionic sympathetic nerve fibres are induced (Jimenez-Andrade et al. 2010a) in close proximity to colonies of $\mathrm{PCa}$ cells, tumour-associated stromal cells and newly formed woven bone, which together form osteosclerotic lesions (Jimenez-Andrade et al. 2010a). This ectopic sensory nerve fibre sprouting appears to be induced particularly by the tumour-associated stromal 


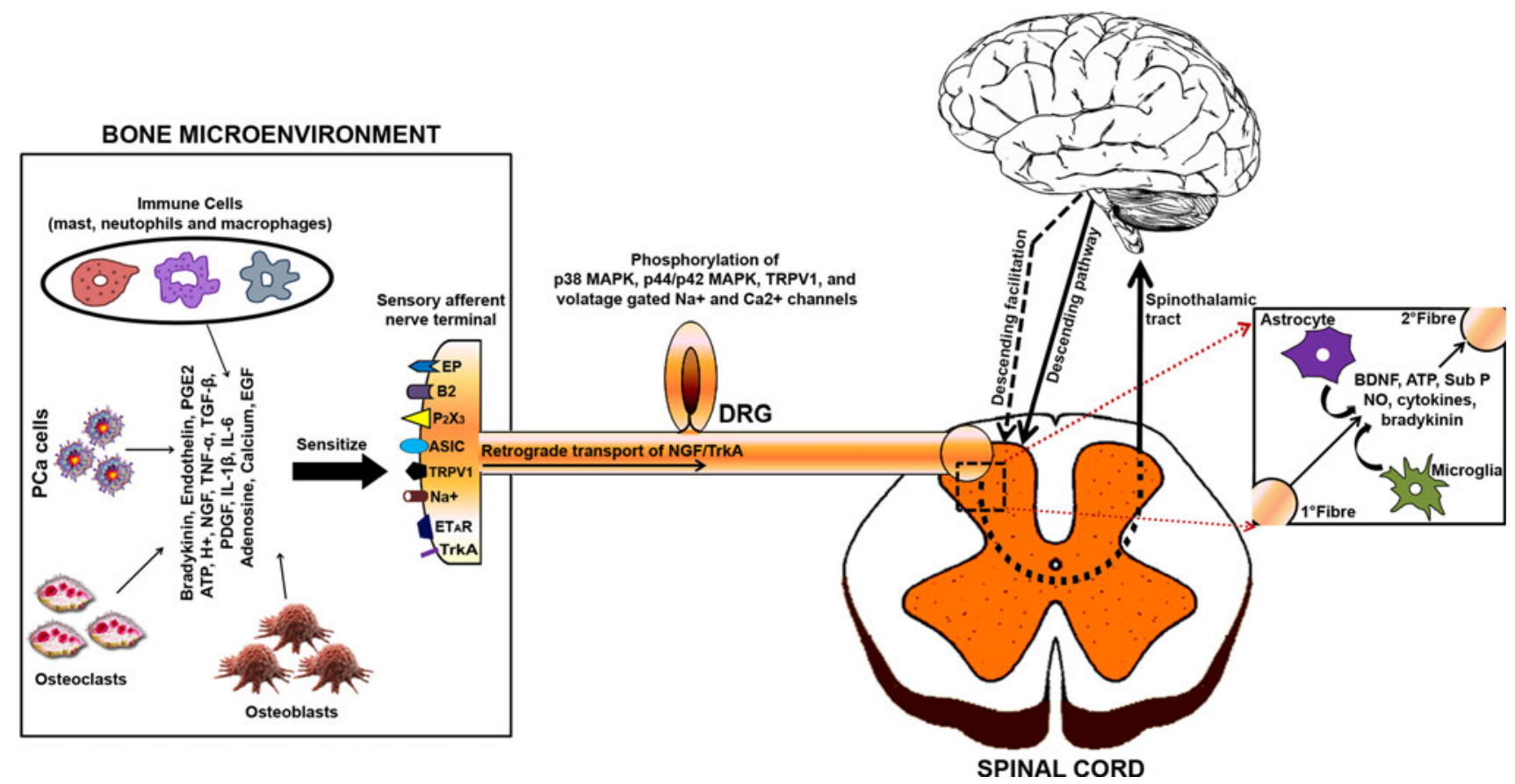

Fig. 4 Pathophysiology of cancer-induced bone pain [adapted from Smith and Muralidharan (2013)]. IL Interleukin, NGF nerve growth factor, TNF tumour necrosis factor, ATP adenosine triphosphate, $\mathrm{H}^{+}$ hydrogen ion, $P G E 2$ prostaglandin, $T G F-\beta$ transforming growth factor, $P D G F$ platelet-derived growth factor, $E G F$ epidermal growth

cells and confined to sensory fibres that co-express the high-affinity NGF receptor, tyrosine kinase (Trk) A receptor (TrkA) (Jimenez-Andrade et al. 2010a). Retrograde transport of NGF via the peripheral terminals of abnormally sprouting sensory nerve fibres to the cell bodies of primary sensory neurons in the dorsal root ganglia (DRGs) likely contributes to first-order sensory neuron hyperexcitability via multiple mechanisms. Such mechanisms include upregulated synthesis of pro-nociceptive mediators (Mantyh et al. 2011), activation of p38 mitogenactivated protein kinase (MAPK) (Ji et al. 2002) and p44/ p42 MAPK (Averill et al. 2001)-induced sensitization (phosphorylation) of the TRPV1 (Ji et al. 2002) as well as voltage-gated sodium (Hudmon et al. 2008; Stamboulian et al. 2010) and calcium channels (Martin et al. 2006). Together, these observations strongly implicate a role for NGF/TrkA signalling in the maintenance of PCIBP. In further support of this notion, preventive or late administration of an anti-NGF antibody to mice with $\mathrm{PCa}$ cellinduced tumours in the femur significantly attenuated PCIBP by blocking tumour-induced ectopic nerve fibre sprouting and neuroma formation in the bone periosteum (Jimenez-Andrade et al. 2011; Halvorson et al. 2005).

Interestingly, NGF-dependent nerve fibre changes observed in PCIBP (Jimenez-Andrade et al. 2011; Halvorson et al. 2005) have also been shown in rodent models factor, $\mathrm{Na}^{+}$sodium ion channel, $\mathrm{B} 2$ bradykinin receptor, $\mathrm{P} 2 \mathrm{X} 3$ purinergic receptor, $A S I C$ acid-sensing ion channel, $E P$ prostaglandin receptor, $E T_{A} R$ endothelin A receptor, TrkA tyrosine kinase A, TRPVI transient receptor potential vanilloid $1, S u b P$ substance $\mathrm{P}, B D N F$ brain-derived neurotropic factor, $N O$ nitric oxide

of peripheral nerve injury-induced neuropathic pain (Peleshok and Ribeiro-da-Silva 2011; Zhang and Strong 2008). For example, in rats with sciatic nerve injury, axonal sprouting of injured sciatic nerve sensory fibres was correlated with peak hindpaw hypersensitivity (Sommer et al. 1995) as well as with sympathetic nerve fibre sprouting in glabrous skin (Yen et al. 2006). In other work, unilateral sciatic nerve administration of NGF in noninjured rats induced dose-dependent thermal hyperalgesia together with demyelination and axonal sprouting to mimic the changes seen in nerve-injured rats (Ruiz et al. 2004). Following sciatic nerve transection (SNT) in rats, local administration of an NGF-sequestering fusion protein (TrkA-IgG) at the site of nerve transection blocked neuroma formation as well as the development of neuropathic pain behaviours (Kryger et al. 2001). Importantly, as there were no significant changes in the cellular characteristics of the DRGs of SNT-rats that received TrkA-IgG treatment, c.f. control rats, TrkA-IgG appears to act only at the local site of nerve transection (Kryger et al. 2001).

Central pain mechanisms

Tissue inflammation or peripheral nerve injury-induced sensitization of peripheral sensory nerve fibres results in their hyperexcitability, characterized by ectopic discharge 
to induce so-called 'central sensitization' in the dorsal horn of the spinal cord and supraspinally. Central sensitization is underpinned by multiple neuroplastic changes in the functional responsiveness of nociceptive circuits due to increased membrane excitability and/or reduced inhibition in the spinal cord (Gordon-Williams and Dickenson 2007). In rodent models of inflammatory and neuropathic pain, augmented glutamate signalling via $N$-Methyl-D-aspartic acid (NMDA), $\alpha$-amino-3-hydroxy-5-methyl-4-isoxazolepropionic acid receptor (AMPAR), group I-III metabotropic glutamate receptors (mGluR), as well as brain-derived neurotrophic factor (BDNF), Sub P, CGRP, nitric oxide (NO) and bradykinin have all been implicated in the mechanisms underpinning central sensitization (Latremoliere and Woolf 2009). In addition, degeneration of inhibitory GABAergic interneurons in the spinal cord (Scholz et al. 2005) and/or enhanced descending 5- $\mathrm{HT}_{3}$ mediated facilitation (Gordon-Williams and Dickenson 2007) may contribute to central sensitization. Apart from neuronal changes, peripheral nerve injury also induces activation of microglia and astrocytes in the CNS, which under normal conditions perform "house-keeper" roles to support on-going function and survival of neurons. Once activated, microglia and astrocytes release multiple pronociceptive substances including cytokines, chemokines, neurotrophic factors, adenosine triphosphate (ATP), NO and excitatory amino acids that enhance pain by amplifying CNS neuron hyperexcitability (Fig. 4) (Vallejo et al. 2010).

In a rat model of PCIBP, activation of microglia and astrocytes together with upregulation of IL- $1 \beta$ developed in the ipsilateral spinal cord of rats exhibiting pain behaviours at 20 days after unilateral ITI of rat prostate cancer cells (Zhang et al. 2005). In other work, IL-1 $\beta$ facilitated PCIBP by enhancing phosphorylation of the NR1 subunit of the NMDA receptor whereas pain behaviour was blocked by treatment with an IL-1 receptor antagonist (Zhang et al. 2008a).

\section{Knowledge gaps in the pathobiology of PCIBP}

The recent advent of rodent models of PCIBP has enabled the relative contributions of invading tumour cells vis-a-vis factors related to the bone microenvironment, to the pathogenesis of PCIBP to be examined. However, additional research is needed to elucidate the biochemical and molecular mechanisms that underlie cross talk between these various aspects of PCIBP.

Research using murine models of breast cancer- and osteolytic sarcoma-induced bone pain implicates a unique functional responsiveness of the noxious circuitry in spinal cord sensitization (Table 2). This is characterized by a neurochemical signature of pro-hyperalgesic mediators in the DRGs (Table 3) and the dorsal horn of the spinal cord
(Table 4) that differ from those for neuropathic and/or inflammatory pain. For example, in fibrosarcoma-bearing mice, the proportion of wide dynamic range (WDR) neurons was unchanged (Khasabov et al. 2007), whereas in breast cancer-induced bone tumour-bearing rats, the proportion of WDR neurons increased significantly (Urch et al. 2003). Hence, it is important to be aware of the potential for between-tumour differences in the mechanisms underpinning central sensitization in the spinal cord as a result of cancer-induced bone metastases.

At present, the functional responsiveness of noxious circuitry and knowledge on the neurochemical signature of pro-hyperalgesic mediators in the DRGs and spinal cord of rodent models of PCIBP is poorly understood, and so this knowledge gap needs to be addressed. An improved understanding of the neurobiology of PCIBP has the potential to identify new targets for use in drug discovery programs aimed at producing a new generation of analgesics and/or adjuvant drugs for the improved relief of intractable pain due to advanced prostate cancer-induced bone pain.

\section{Therapeutic strategies for the management of PCIBP}

The pathobiology of prostate cancer-induced bone pain is underpinned by neuroplastic changes at multiple levels of the somatosensory system, in addition to contributions from immune, stromal and tumour-associated factors in the bone microenvironment. Hence, it is possible that the quality of life and survival of patients with metastasisinduced PCIBP may be improved not only by analgesic agents (see reviews by Cleary 2007 and Nersesyan and Slavin 2007), but also by treatments that inhibit the tumourigenic process including metastasis to bone. Hence, an overview of novel therapeutic agents aimed at blocking progression of prostate cancer-induced metastasis to bone, that have at least reached Phase III clinical trials, is provided in the next section. A schematic diagram summarizing a range of potential therapeutic targets for novel agents aimed at reducing prostate cancer-induced bone metastasis is shown in Fig. 5.

Therapeutic agents with defined analgesic potential

\section{Radiotherapy}

Approximately 20 years ago, the Radiation Therapy Oncology Group reported that 80-90\% of patients receiving radiotherapy (RT) for osseous metastases experience partial to complete pain relief within 10-14 days of RT initiation (Tong et al. 1982). Three types of RT are used for treatment of bone metastases, viz external beam radiotherapy (EBRT), 
Table 2 Comparative electrophysiological findings between rodent models of peripheral nerve injury and cancer-induced bone pain

\begin{tabular}{|c|c|c|}
\hline Neuropathic pain (NP) models & Breast cancer-induced bone pain & Ostelolytic fibrosarcoma-induced bone pain \\
\hline $\begin{array}{l}\text { Significant increase in the peripheral receptive } \\
\text { field size in both superficial and deeper } \\
\text { neurons of the spinal cord (Suzuki et al. } \\
\text { 2000) }\end{array}$ & $\begin{array}{l}\text { Significant increase in the peripheral receptive } \\
\text { field size in only superficial neurons (Urch } \\
\text { et al. 2003; Donovan-Rodriguez et al. 2004) }\end{array}$ & $\begin{array}{l}\text { Significant increase in the peripheral receptive } \\
\text { field size in only superficial neurons } \\
\text { (Yanagisawa et al. 2010) }\end{array}$ \\
\hline $\begin{array}{l}\text { Increased levels of ongoing activity of both } \\
\text { WDR and HT neurons (Sotgiu et al. 1994) }\end{array}$ & $\begin{array}{l}\text { Increased levels of ongoing activity of WDR, } \\
\text { but not HT neurons (Urch et al. 2003) }\end{array}$ & $\begin{array}{l}\text { Increased levels of ongoing activity of WDR, } \\
\text { but not HT neurons (Khasabov et al. 2007; } \\
\text { Yanagisawa et al. 2010; Simone et al. 2008) }\end{array}$ \\
\hline $\begin{array}{l}\text { Increase in the proportion of WDR neurons in } \\
\text { the NP rats }(32 \%) \text {, c.f. control rats }(22 \%) \\
\text { (Liu et al. 2011) }\end{array}$ & $\begin{array}{l}\text { Increase in the proportion of WDR neurons in } \\
\text { the tumour-bearing rats (47\%), c.f. control } \\
\text { rats }(26 \%) \text { (Urch et al. 2003; Donovan- } \\
\text { Rodriguez et al. 2004) }\end{array}$ & $\begin{array}{l}\text { No change in the proportion WDR neurons in } \\
\text { tumour-bearing mice }(64 \%) \text {, c.f. control } \\
\text { mice }(56 \%) \text { (Khasabov et al. } 2007)\end{array}$ \\
\hline $\begin{array}{l}\text { Sensitization of both WDR and HT neurons } \\
\text { contribute to mechanical stimuli (Sotgiu } \\
\text { et al. 1995) }\end{array}$ & $\begin{array}{l}\text { Sensitization of WDR, but not HT, neurons } \\
\text { contribute to tumour-evoked mechanical } \\
\text { stimuli (Urch et al. 2003; Donovan- } \\
\text { Rodriguez et al. 2004) }\end{array}$ & $\begin{array}{l}\text { Sensitization of WDR, but not HT, neurons } \\
\text { contribute to tumour-evoked mechanical } \\
\text { stimuli (Khasabov et al. 2007; Yanagisawa } \\
\text { et al. 2010; Simone et al. 2008) }\end{array}$ \\
\hline $\begin{array}{l}\text { WDR neurons do not exhibit sensitization to } \\
\text { heat stimuli (Laird and Bennett 1993) }\end{array}$ & $\begin{array}{l}\text { Sensitization of WDR neurons to heat stimuli } \\
\text { (Urch et al. 2003; Donovan-Rodriguez et al. } \\
\text { 2004) }\end{array}$ & $\begin{array}{l}\text { Sensitization of WDR neurons to heat stimuli } \\
\text { (Simone et al. 2008; Khasabov et al. 2007) }\end{array}$ \\
\hline $\begin{array}{l}\text { The amplitude and frequency of sEPSCs of SG } \\
\text { neurons were unaffected (Okamoto et al. } \\
\text { 2001; Kohno et al. 2003) }\end{array}$ & NA & $\begin{array}{l}\text { The amplitude of sEPSCs of SG neurons are } \\
\text { increased, but their frequencies remained } \\
\text { unchanged (Yanagisawa et al. 2010) }\end{array}$ \\
\hline $\begin{array}{l}\text { Increase in A } \beta \text { fiber-mediated EPSCs of SG } \\
\text { neurons when compared with control } \\
\text { animals (Okamoto et al. 2001; Kohno et al. } \\
\text { 2003) }\end{array}$ & NA & $\begin{array}{l}\text { No change in A } \beta \text { fiber-mediated EPSCs of SG } \\
\text { neurons when compared with control } \\
\text { animals (Yanagisawa et al. 2010) }\end{array}$ \\
\hline $\begin{array}{l}\text { Spinal sensitization is present at lumbar levels } \\
\text { where central terminals of primary afferent } \\
\text { sensory neurons innervate (Okamoto et al. } \\
\text { 2001; Kohno et al. 2003) }\end{array}$ & NA & $\begin{array}{l}\text { Spinal sensitization is present throughout } \\
\text { multiple lumbar spinal levels rather than just } \\
\text { the segments in which the central terminals } \\
\text { of primary afferent sensory neurons } \\
\text { innervate (Yanagisawa et al. 2010) }\end{array}$ \\
\hline
\end{tabular}

sEPSCs spontaneous excitatory postsynaptic currents, $S G$ substantia gelatinosa, WDR wide dynamic range, $H T$ high threshold neurons, $N A$ not assessed

Table 3 Comparison of neurochemical alterations in primary afferent sensory neurons in rodent models of inflammatory pain [Freund's complete adjuvant (CFA)], spinal nerve ligation (SNL), sciatic nerve transection (SNT) and CIBP (adapted from Honore et al. 2000b; Peters et al. 2005; Braz and Basbaum 2010; Guo et al. 2007; Kim et al. 2009a)

\begin{tabular}{lcccc}
\hline Makers & CFA & SNL & SNT & CIBP \\
\hline Sub P & $\longleftrightarrow$ & $\searrow$ & $\searrow$ & $\searrow$ \\
IB4 & $\longleftrightarrow$ & $\searrow$ & $\searrow$ \\
CGRP & $\longleftrightarrow$ & $\searrow$ & $\longleftarrow$ \\
GAL & $\longleftrightarrow$ & $\nearrow$ & $\nearrow$ \\
NPY & $\longleftrightarrow$ & $\nearrow$ & $\nearrow$ \\
ATF3 & $\longleftrightarrow$ & $\nearrow$ & $\nearrow$ & $\nearrow$ \\
GFAP & $\nearrow$ & $\nearrow$ & $\nearrow$ & $\nearrow$
\end{tabular}

The above symbols represent a significant increase $(\nearrow)$, decrease $(\searrow)$ or no significant changes $(\leftrightarrow)$ in the immunofluorescence of neurochemical markers in lumbar DRGs

$S P$ substance $\mathrm{P}, I B 4$ isolectin B4, CGRP calcitonin gene-related peptide, GAL galanin, $N P Y$ neuropeptide Y, ATF3 activating transcription factor 3, GFAP glial fibrillary acidic protein

hemi-body irradiation $(\mathrm{HBI})$ and radiopharmaceuticals (Pandit-Taskar et al. 2004). Systematic review shows that EBRT, whether given as single or multiple fractions, produces $50 \%$ pain relief in $41 \%$ of patients and complete pain relief at 1 month in $24 \%$ of patients (McQuay et al. 2000). Although HBI provides rapid pain relief, it comes at the expense of toxicity (Lin and Ray 2006). Systemic review and meta-analysis of randomized controlled clinical trials found 
Table 4 Comparison of the neurochemistry of inflammatory pain, spinal nerve ligation- induced pain, sciatic nerve transection and bone cancer pain in the dorsal horn of the spinal cord of rodent models

\begin{tabular}{|c|c|c|c|c|}
\hline Makers in laminae I-II & CFA & SNL & SNT & CIBP \\
\hline Sub P & $\nearrow$ & $\searrow$ & $\searrow$ & $\longleftrightarrow$ \\
\hline IB4 & $\longleftrightarrow$ & $\searrow$ & $\searrow$ & $\longleftrightarrow$ \\
\hline CGRP & $\nearrow$ & $\searrow$ & $\searrow$ & $\longleftrightarrow$ \\
\hline GAL & $\longleftrightarrow$ & $\nearrow$ & $\nearrow$ & $\longleftrightarrow$ \\
\hline NPY & $\longleftrightarrow$ & $\nearrow$ & $\nearrow$ & $\longleftrightarrow$ \\
\hline DYN & $\longleftrightarrow$ & $\longleftrightarrow$ & $\nearrow$ & $\longleftrightarrow$ \\
\hline GFAP & $\nearrow$ & $\nearrow$ & $\nearrow$ & $\nearrow$ \\
\hline OX-42 & $\longleftrightarrow$ & $\nearrow$ & $\longleftrightarrow$ & $\longleftrightarrow$ \\
\hline
\end{tabular}

The above symbols represent a significant increase $(\nearrow)$, decrease $(\searrow)$ or no significant changes $(\leftrightarrow)$ in the immunofluorescence of neurochemical markers in laminae I-II of the spinal cord

$S P$ substance $\mathrm{P}, I B 4$ isolectin $\mathrm{B} 4, C G R P$ calcitonin gene-related peptide, $G A L$ galanin, $N P Y$ neuropeptide $\mathrm{Y}, A T F 3$ activating transcription factor 3, GFAP glial fibrillary acidic protein, $O X-42$ microglial marker

Fig. 5 Schematic diagram summarizing a range of potential therapeutic targets for novel drugs aimed at reducing prostate cancer-induced bone metastasis [adapted from Tu and Lin (2008)]

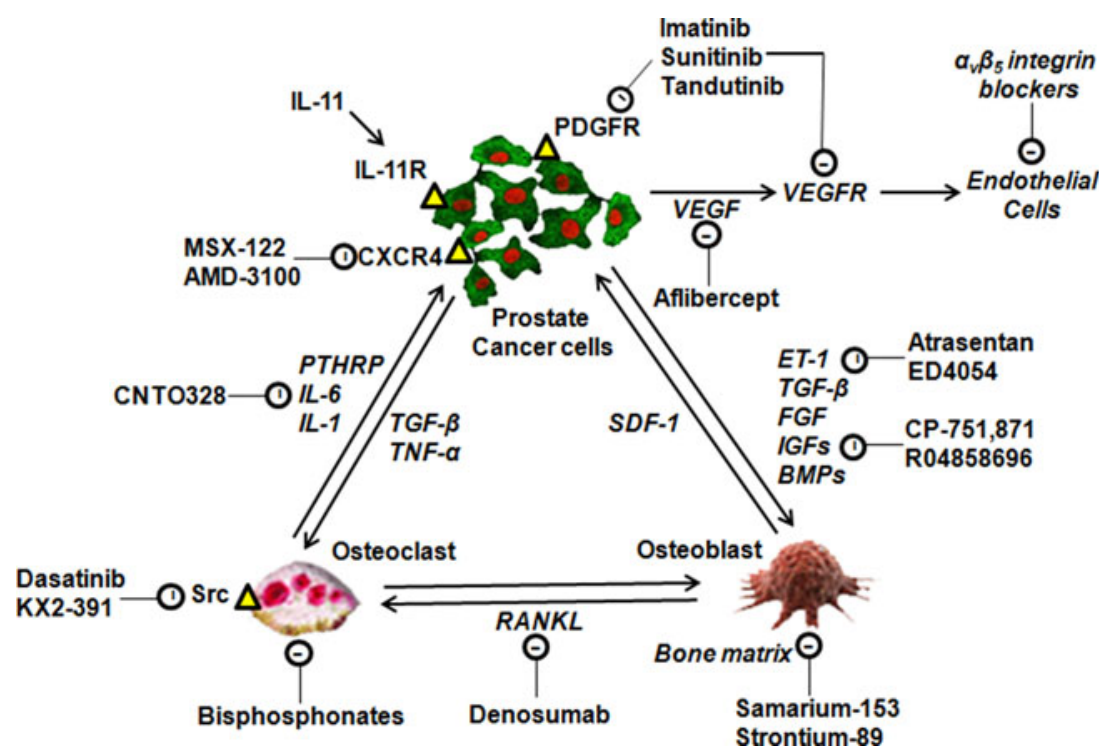

that single-fraction radiotherapy with $1 \times 8 \mathrm{~Gy}$ is as effective for pain relief as multi-fraction regimens such as $5 \times 4$ Gy in 1 week or $10 \times 3$ Gy in 2 weeks (Wu et al. 2003; Sze et al. 2003, 2004). More recently, a prospective study involving 91 patients with painful bone metastases who were treated with a median total dose of 46 Gy (Nomiya et al. 2010), found that complete and partial pain relief ( $\geq 50 \%$ ) were obtained in 49 and $91 \%$ of patients, respectively (Nomiya et al. 2010). Although the optimal dose fractionation for radiation of metastatic bone lesions has been controversial, an internet survey of radiation oncologists, with members participating from the American Society for Radiology Oncology, Canadian Association of Radiation Oncology, and Royal Australian and New Zealand College of Radiologists, concluded that the most accepted fractionation schemes are 8 Gy in a single fraction and $30 \mathrm{~Gy}$ in ten fractions (Fairchild et al. 2009). (adapted from Honore et al. 2000a, 2009; Schwei et al. 1999; Raghavendra et al. 2004; Lin et al. 2007) 
patient survival and quality of life. A Cochrane review of the efficacy and safety of radioisotopes in patients with metastatic bone pain concluded that there was evidence to support their use as analgesics with a number needed to treat (NNT) to achieve complete and complete/partial pain relief at 5 and 4, respectively (Roque et al. 2011). More recently, Phase II clinical studies of the $\alpha$-emitting radioisotope, radium (Ra-223), demonstrated significant improvements in overall survival, time to first skeletal-related events (SRE), pain response and biochemical parameters with very good tolerability, in men with castration-resistant prostate cancer (CRPC) metastasized to bone (Parker et al. 2013; Nilsson et al. 2012). A Phase III randomized clinical trial (ALSYMPCA) investigating the analgesic efficacy, overall survival benefit and safety profile of Ra-223 $(50 \mathrm{kBq} / \mathrm{kg}$ i.v.) is currently ongoing (NCT00699751). At interim analysis, Ra-223 demonstrated significant improvements in overall survival, pain response and time to initial EBRT or opioid use (Parker et al. 2012; Nilsson et al. 2013).

\section{Bisphosphonates}

Bisphosphonates (BPs) are pyrophosphate analogues that bind avidly to hydroxyapatite bone mineral surfaces and are selectively internalized by osteoclasts (Russell et al. 1999), thereby disturbing the cytoskeleton and loss of actin rings leading to osteoclast apoptosis (Russell et al. 1999). The anti-proliferative, anti-angiogenic and apoptotic properties (see Clezardin 2011 for review) of BPs is supported by efficacy data from rodent models (Hall and Stoica 1994; Yoneda et al. 1997; Clohisy et al. 2001).

BPs are effective in reducing PCIBP and the occurrence of SREs, either when used alone or concomitantly with radiation therapy (Manas et al. 2008; Lilleby 2007; Yuen et al. 2006; Rodrigues et al. 2004). A Cochrane review of BPs in metastatic bone disease concluded that the NNT for analgesic efficacy was 11 at 4 weeks but reduced to 7 at 12 weeks (Wong and Wiffen 2002). Zoledronic acid (Zometa $^{\circledR}$, Novartis) and pamidronate (Aredia ${ }^{\circledR}$, Novartis) were approved by the US FDA for the treatment of metastatic bone complications in 1995 and 2002, respectively (Saylor and Smith 2010). Although BPs may alleviate PCIBP, more research is needed to guide the choice of BPs as well as to optimize the treatment schedule (Yuen et al. 2006).

\section{Non-steroidal anti-inflammatory drugs (NSAIDs)}

A meta-analysis of 25 randomized controlled trials related to the use of NSAIDs in cancer pain in humans found that although NSAIDs significantly reduced cancer-related pain above placebo, it was not possible to draw conclusions on their efficacy for relief of cancer-induced bone pain as pain due to bony metastases were not reported on separately from other cancer pain (Eisenberg et al. 1994). More recently, a Cochrane review of the use of NSAIDs in 42 randomized clinical trials, either alone or in combination with opioids for the relief of cancer pain, concluded that NSAIDs were more effective than placebo, but that evidence to support the superior safety or efficacy of one NSAID over another, was lacking (McNicol et al. 2005). Despite the aforementioned limitations, NSAIDs administered either alone or in combination with opioids, are recommended for the relief of metastatic bone pain (IASP 2009). Selective COX-2 inhibitors may have therapeutic benefit due to their anti-inflammatory and anti-tumourigenic properties (Sumitani et al. 2001). In support of this notion, acute administration of selective COX-2 inhibitors to rodents with cancer-induced bone pain attenuated hypersensitivity (pain) behaviours, whereas chronic treatment reduced tumour burden, osteoclast destruction in addition to producing significant pain relief (Sabino et al. 2002).

The findings of Phase III clinical trials on the analgesic efficacy of radiopharmaceuticals, including strontium-89 (Sr-89), samarium-153 (Sm-153), rhenium-186 (Re-186) and radium-223 (Ra-223), as well as BPs such as zoledronic acid and pamidronate, in patients with prostate cancer-induced bone pain are summarized in Table 5. A detailed review of randomized clinical studies on the analgesic efficacy of radiotherapy may be found elsewhere (see Rades et al. 2010).

\section{Metastasis or tumourigenesis inhibitors}

In the next section, we provide an overview of therapeutic agents shown to slow the progression of prostate cancerinduced metastasis to the skeleton; detailed reviews may be found elsewhere (see Russo et al. 2010; Saad and Lipton 2010b; Saylor et al. 2013). As the analgesic efficacy for most of these agents in patients with PCIBP has not been reported on, this is a knowledge gap that remains to be addressed.

\section{RANKL inhibition}

RANK/RANKL/OPG signalling plays a key role in the early stages of PCIBP (Castellano et al. 2011). OPG is suggested to be a promising agent for the treatment of PCIBP that acts by reducing osteoclast function to diminish tumour-induced bone destruction (Body et al. 2003). However, OPG is poorly selective and also inhibits TRAIL, which promotes tumour cell apoptosis (Neville-Webbe et al. 2004).

Denosumab (AMG 162) is a human monoclonal $\mathrm{IgG}_{2}$ antibody directed against RANKL, with an extremely high 


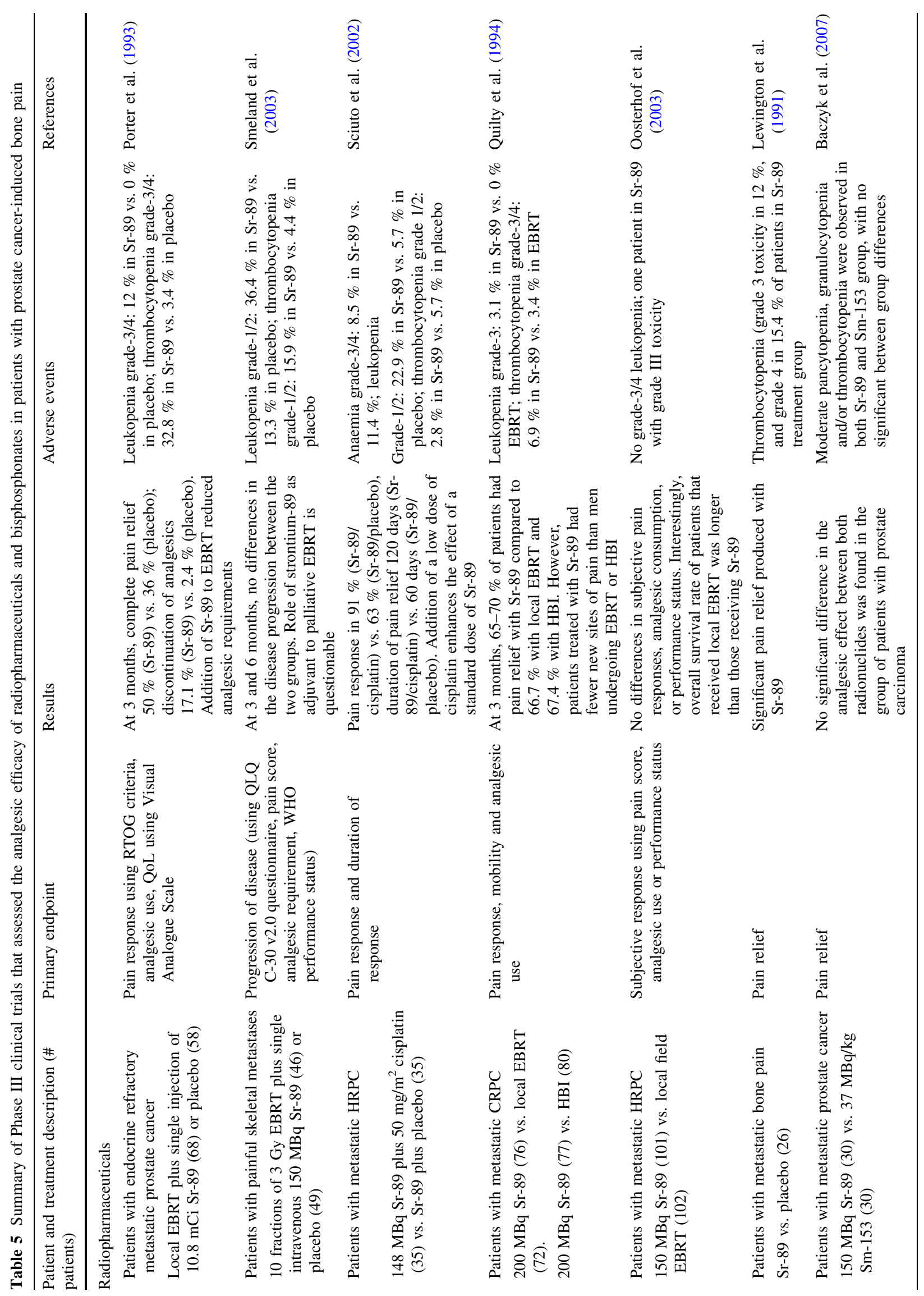




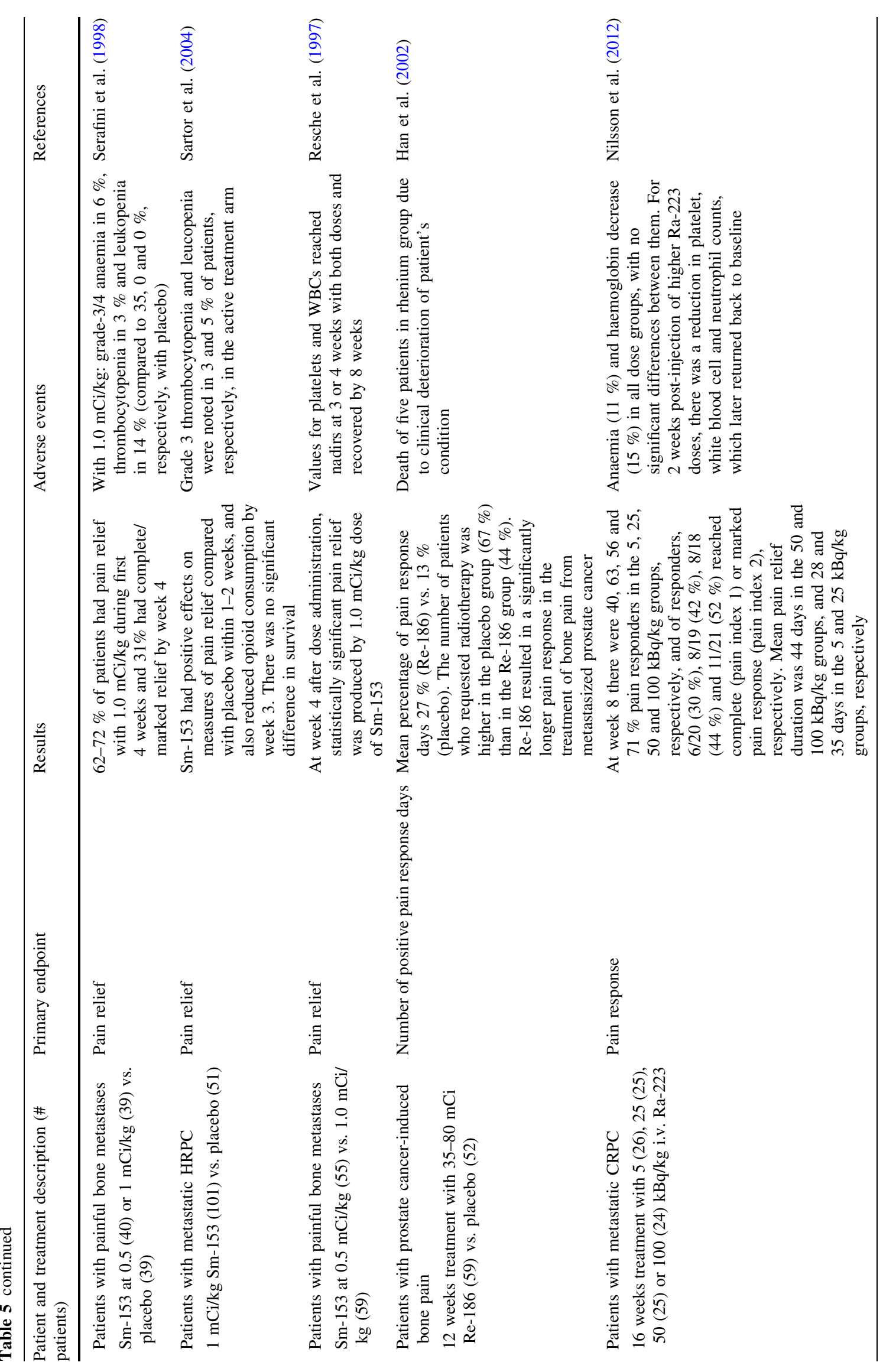




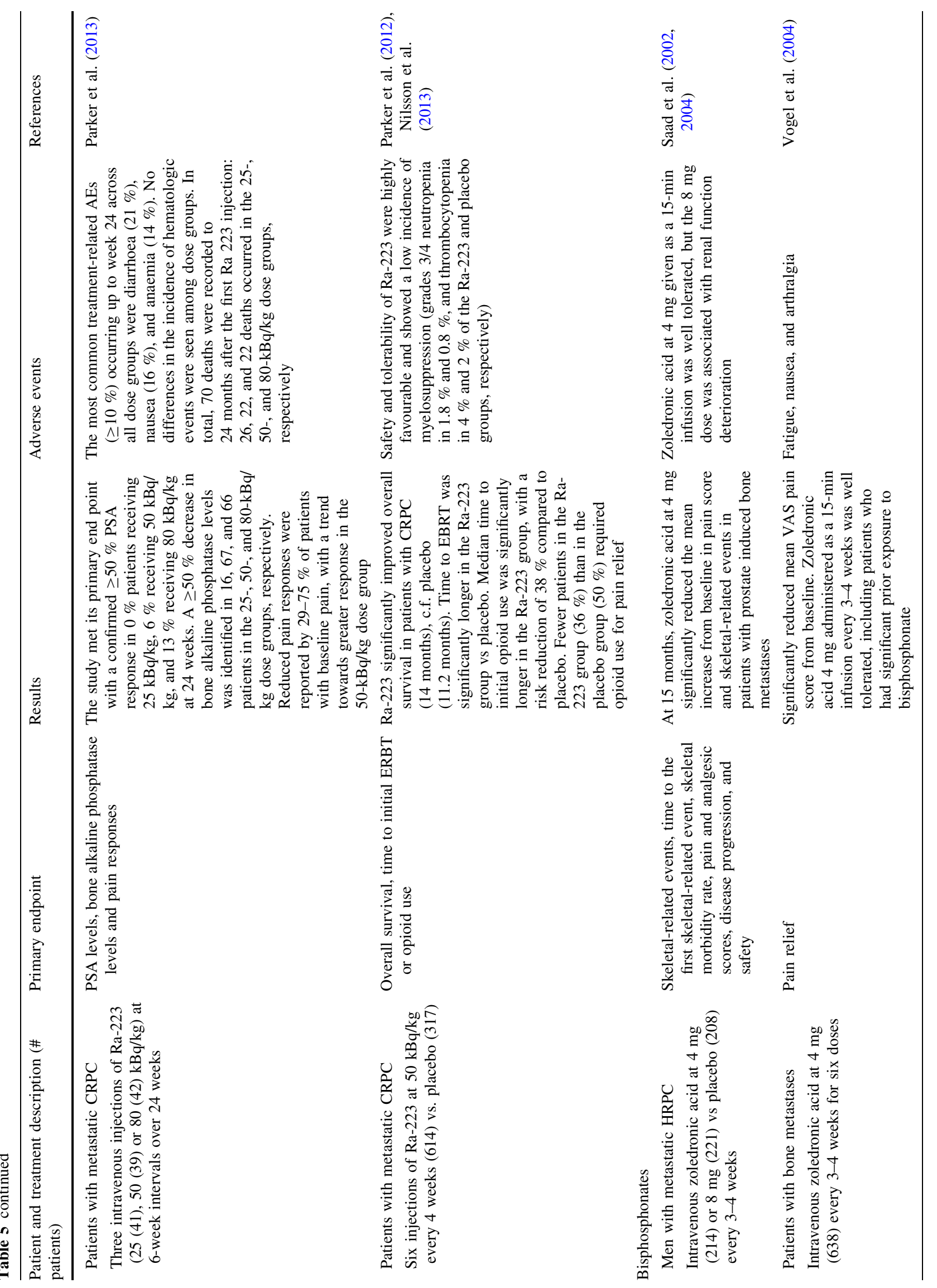


affinity for human RANKL (Schwarz and Ritchlin 2007). With a greater decrease in bone marker turnover and a longer duration of action, AMG 162 is more potent than AMGN-0007, a recombinant OPG. A large Phase III randomized clinical trial demonstrated the superiority of denosumab over zoledronic acid in prevention of SREs in men with bone metastases and CRPC (Fizazi et al. 2011). Based on these findings, denosumab Xgeva $^{\mathrm{TM}}$, Amgen Inc.) was approved by the US FDA for the prevention of SREs in patients with bone metastases from solid tumours.

\section{Endothelin-1 antagonists}

The importance of the ET axis in cell growth, invasion, regulation of apoptosis, and stimulation of angiogenesis has led to the concept of ET antagonism (Lalich et al. 2007). The orally active $\mathrm{ET}_{\mathrm{A}} \mathrm{R}$ antagonist, atrasentan (ABT-627, Xinlay $^{\mathrm{TM}}$, Abbott) (Opgenorth et al. 1996), attenuated disease progression as well as reduced morbidity in patients with PCa-induced bone metastases (Lalich et al. 2007). Phase I clinical trials of atrasentan reduced pain in $70 \%$ of patients when evaluated using a VAS (Visual Analogue Scale), and decreased PSA levels in $\sim 45 \%$ of patients (Carducci et al. 2002; Zonnenberg et al. 2003; Ryan et al. 2004).

Phase II clinical trials of atrasentan reduced PSA levels and significantly delayed disease progression (Carducci et al. 2003; Nelson et al. 2003). In addition, expression levels for markers of bone formation and resorption mirrored the preclinical data (Carducci et al. 2003; Nelson et al. 2003). Although subsequent Phase III clinical trials of atrasentan in men with metastatic hormone-refractory PCa (mHRPC) produced favourable trends for time to PSA progression and change in bone alkaline phosphatase levels, there was no delay in disease progression (Carducci et al. 2007; Nelson et al. 2008).

Zibotentan (ZD-4054, AstraZeneca) is an endothelin antagonist that reportedly has a beneficial impact on $\mathrm{PCa}$ progression and overall patient survival (James et al. 2009; Schelman et al. 2011). A preliminary clinical study of the safety and efficacy of ZD4054 (Zibotentan) in combination with docetaxel (Taxotere) in patients with metastatic HRPC showed a favourable safety and tolerability profile for this drug combination in patients with metastatic HRPC (Trump et al. 2011).

\section{Src inhibition}

Src, a non-receptor tyrosine kinase, is the prototypic member of the Src-family of kinases (SFKs) (Summy and Gallick 2003). SFKs are components of signal transduction 
pathways involved in normal cellular growth, proliferation, angiogenesis and motility, which when deregulated promote tumour progression (Kim et al. 2009b). Overexpression of Src in osteoclasts (Horne et al. 1992) has been linked to cancer progression (Asim et al. 2008). PTHrP and IL-8 are important mediators in bone metastases that activate the androgen receptor which is implicated in Src signalling (Lee et al. 2001, 2004; DaSilva et al. 2009). Given these roles for Src, it is not surprising that Src inhibitors have emerged as therapeutics in the treatment of PCa (Kim et al. 2009b). Several in vitro and in vivo studies have demonstrated potential anti-tumour and anti-osteoclast activity of the Src inhibitors, dasatinib (BMS-354825, Bristol-Myers-Squibb) and saracatinib (AZD-0530, AstraZeneca) (Nam et al. 2005; Chang et al. 2008; Park et al. 2008; Vandyke et al. 2009; Brownlow et al. 2009; Araujo et al. 2009; Koreckij et al. 2009). Dasatinib (Sprycel ${ }^{\circledR}$, Bristol-Myers-Squibb) is approved for treatment of imatinib-resistant chronic myelogenous leukaemia and Philadelphia chromosome-positive acute lymphoblastic leukaemia (FDA 2010).

In a phase I clinical trial, dasatinib prevented apparent cancer progression in $43 \%$ of patients and $51 \%$ of patients achieved a $\geq 40 \%$ reduction in levels of uNTX (Araujo et al. 2012). In a subsequent Phase II clinical trial, there was a $\geq 35 \%$ reduction in levels of uNTX in $49 \%$ of patients and a significant reduction in BAP and PSA levels in 73 and $59 \%$ of patients, respectively (Yu et al. 2009, 2011). Two different dosage schedules of dasatinib were evaluated in a phase II clinical trial and a phase II extension trial in patients with metastatic CRPC who had not received prior chemotherapy ( $\mathrm{Yu}$ et al. 2009, 2011). These studies showed a reduction in levels of uNTX and BAP (Yu et al. 2009, 2011). Phase I and II clinical trials of saracatinib also showed a positive correlation with respect to cancer progression and PSA levels (Lara et al. 2009; Hannon et al. 2010). The results of a Phase III clinical trial of dasatinib (NCT00744497) are awaited, which will provide the first opportunity to more fully assess the potential of Src inhibition as a strategy to extend survival in patients with PCa-induced bone pain.

KX2-391 (Kinex Pharmaceuticals) is a specific Src inhibitor (Naing et al. 2013) that binds to the peptide substrate-binding site of Src rather than its ATP-binding site (Naing et al. 2013). A recently completed single-arm Phase II clinical study that evaluated the efficacy of KX2391 in men with bone metastatic CRPC who had not received prior chemotherapy (NCT01074138) showed a modest reduction in levels of bone turnover markers (Antonarakis et al. 2013). However, it failed to show antitumour activity at the dose ( $40 \mathrm{mg}$ twice daily) of $\mathrm{KX} 2$ 391 evaluated (Antonarakis et al. 2013).
New therapeutics in development for alleviation of PCIBP

\section{Cathepsin K inhibitor}

Cathepsin $\mathrm{K}$ is a lysosomal cysteine protease secreted by osteoclasts that degrades the extracellular matrix during the process of bone resorption (Wilson et al. 2009). Its significance in bone remodelling is evident by the osteopetrotic phenotype observed in cathepsin K-null mice (Saftig et al. 1998). Expression of cathepsin K has been found in many malignancies, including prostate and breast cancers (Brubaker et al. 2003; Littlewood-Evans et al. 1997). The only cathepsin $\mathrm{K}$ inhibitor studied in humans, odanacatib (MK822, Merck), is still in its early stages of development (Rachner et al. 2012). Although the efficacy of odanacatib is as yet unknown in patients with prostate cancer, odanacatib has shown promising results in clinical trials of osteoporosis in post-menopausal women (Stoch et al. 2009; Bone et al. 2010; Eisman et al. 2011) and in patients with breast cancerinduced metastatic bone disease (Jensen et al. 2010).

\section{Integrin inhibitors}

Integrins are heterodimeric adhesion receptors that regulate cell adhesion, migration, invasion and motility (Millard et al. 2011). The integrins, $\alpha v \beta 3$ and $\alpha v \beta 5$, are involved in metastases in men with PCa (Seftor et al. 1992; Knox et al. 1994; Schneider et al. 2011). The integrin, $\alpha v \beta 3$, is the most abundant in osteoclasts and is critical in osteoclast formation and activity (Clover et al. 1992; Nakamura et al. 2007). Antibodies that bind and block av $\beta 3$, inhibit bone resorption (Nakamura et al. 2007). Vitaxin ${ }^{\circledR}$ (MEDI-522), a humanized monoclonal antibody that blocks $\alpha \mathrm{v} \beta 3$ integrin, is in early clinical development for metastatic melanoma and PCa (Gramoun et al. 2007). In a small multicenter, randomized, double-blind clinical study involving 21 patients with bone metastases and metastatic HRPC, an orally active non-peptide small molecule inhibitor of $\alpha v \beta 3$, MK-0429, was generally well tolerated with evidence of an early reduction in bone turnover; a common side effect was nausea (Rosenthal et al. 2010). However, the short duration of treatment (4 weeks) made it difficult to draw conclusions with respect to drug efficacy (Rosenthal et al. 2010). Hence, clinical trials involving larger numbers of patients with efficacy assessed over a longer period are required to evaluate the potential clinical use of $\alpha v \beta 3$ inhibitors in the treatment of metastatic bone disease and/or PCIBP.

\section{Sclerostin}

Sclerostin is a secreted cysteine-knot protein of the differential screening-selected gene aberrant in the 
neuroblastoma (DAN) family, which includes proteins that antagonize BMP and Wnt signalling (Moester et al. 2010). Although the mechanism by which sclerostin negatively regulates bone formation is still an enigma, sclerostin inhibits differentiation and function of osteoblasts by binding to the first $\beta$-propeller of the low-density lipoprotein-related protein (LRP5/6) (Lin et al. 2009). Sclerostin knockout mice have greater bone mass and bone strength due to increased bone formation ( $\mathrm{Li}$ et al. 2008). A sclerostin antibody (AMG-075, Amgen) is currently in clinical trials (Marenzana et al. 2011; Lewiecki 2011; Tian et al. 2010; Agholme et al. 2010; Eddleston et al. 2009; Li et al. 2009) and so may also have potential as a novel therapeutic for alleviation of PCIBP.

A significant limitation of the aforementioned clinical trials of new treatments for slowing the progression of prostate cancer-induced skeletal metastases is betweenstudy variability in clinical trial endpoints with pain assessments rarely included. Standardization of clinical trial endpoints would facilitate between-treatment comparisons and the development of evidence-based treatment guidelines. With regard to palliative radiotherapy, the International Bone Metastases Consensus Working Party has addressed this issue with recent publication of a set of standard clinical trial endpoints that include assessments of pain and quality of life (Lemke et al. 2012). Widespread adoption of standardized clinical trial endpoints that include assessment of pain and treatment impact on quality of life measures for evaluation of new therapies aimed at slowing the progression of skeletal metastases would greatly facilitate the identification of those treatments that improve patient outcomes.

\section{Conclusion}

The pathobiology of prostate cancer-induced bone pain is complex involving components of neuropathic, inflammatory and ischemic pain arising from ectopic sprouting and sensitization of primary afferent sensory nerve fibres within prostate cancer-invaded bones. Dynamic cross talk between metastatic cancer cells, cellular components of the bone matrix (osteoblasts and osteoclasts) and factors associated with the bone microenvironment contribute to the establishment and maintenance of PCIBP. Hence, it is not surprising that the clinical management of PCIBP requires multimodal treatment involving radiotherapy, analgesics (opioids, NSAIDs), bisphosphonates, radioisotopes and tumouricidal therapies. Further research to gain a deeper understanding of the molecular mechanisms underpinning the bidirectional cross talk between the various elements contributing to the pathobiology of PCIBP is required. The knowledge so gained will be invaluable in guiding drug discovery programs aimed at producing a new generation of efficacious and well-tolerated analgesic/ adjuvant agents for improved relief of intractable pain in patients with advanced skeletal metastases.

Acknowledgments Arjun Muralidharan is supported by an International $\mathrm{PhD}$ Scholarship funded by The University of Queensland.

Conflict of interest The author(s) declare(s) that they have no conflicts of interest to disclose.

Open Access This article is distributed under the terms of the Creative Commons Attribution License which permits any use, distribution, and reproduction in any medium, provided the original author(s) and the source are credited.

\section{References}

Achbarou A, Kaiser S, Tremblay G et al (1994) Urokinase overproduction results in increased skeletal metastasis by prostate cancer cells in vivo. Cancer Res 54:2372-2377

Adwan H, Bauerle TJ, Berger MR (2004) Downregulation of osteopontin and bone sialoprotein II is related to reduced colony formation and metastasis formation of MDA-MB-231 human breast cancer cells. Cancer Gene Ther 11:109-120

Agholme F, Li X, Isaksson $\mathrm{H}$ et al (2010) Sclerostin antibody treatment enhances metaphyseal bone healing in rats. $\mathrm{J}$ Bone Miner Res 25:2412-2418

Akerley W, Butera J, Wehbe T et al (2002) A multiinstitutional, concurrent chemoradiation trial of strontium-89, estramustine, and vinblastine for hormone refractory prostate carcinoma involving bone. Cancer 94:1654-1660

Amato RJ, Hernandez-McClain J, Henary H (2008) Bone-targeted therapy: phase II study of strontium-89 in combination with alternating weekly chemohormonal therapies for patients with advanced androgen-independent prostate cancer. Am J Clin Oncol 31:532-538

Antonarakis ES, Heath EI, Posadas EM et al (2013) A phase 2 study of KX2-391, an oral inhibitor of Src kinase and tubulin polymerization, in men with bone-metastatic castration-resistant prostate cancer. Cancer Chemother Pharmacol 71:883-892

Araujo JC, Poblenz A, Corn P et al (2009) Dasatinib inhibits both osteoclast activation and prostate cancer PC-3-cell-induced osteoclast formation. Cancer Biol Ther 8:2153-2159

Araujo JC, Mathew P, Armstrong AJ et al (2012) Dasatinib combined with docetaxel for castration-resistant prostate cancer: results from a phase 1-2 study. Cancer 118:63-71

Asim M, Siddiqui IA, Hafeez BB et al (2008) Src kinase potentiates androgen receptor transactivation function and invasion of androgen-independent prostate cancer $\mathrm{C} 4-2$ cells. Oncogene 27:3596-3604

Aubin JE (1998) Bone stem cells. J Cell Biochem Suppl 30-31:73-82

Averill S, Delcroix JD, Michael GJ et al (2001) Nerve growth factor modulates the activation status and fast axonal transport of ERK $1 / 2$ in adult nociceptive neurones. Mol Cell Neurosci 18:183-196

Baczyk M, Czepczynski R, Milecki P et al (2007) 89Sr versus 153Sm-EDTMP: comparison of treatment efficacy of painful bone metastases in prostate and breast carcinoma. Nucl Med Commun 28:245-250

Balkwill F (2004) The significance of cancer cell expression of the chemokine receptor CXCR4. Semin Cancer Biol 14:171-179 
Barnes GL, Javed A, Waller SM et al (2003) Osteoblast-related transcription factors Runx2 (Cbfa1/AML3) and MSX2 mediate the expression of bone sialoprotein in human metastatic breast cancer cells. Cancer Res 63:2631-2637

Basbaum AI, Bautusta DM, Scherrer G et al (2009) Cellular and molecular mechanisms of pain. Cell 139:267-284

Bendre MS, Montague DC, Peery T (2003) Interleukin-8 stimulation of osteoclastogenesis and bone resorption is a mechanism for the increased osteolysis of metastatic bone disease. Bone 33:28-37

Berruti A, Dogliotti L, Gorzegno G et al (1999) Differential patterns of bone turnover in relation to bone pain and disease extent in bone in cancer patients with skeletal metastases. Clin Chem 45:1240-1247

Bidard FC, Pierga JY, Vincent-Salomon A et al (2008) A "class action" against the microenvironment: do cancer cells cooperate in metastasis? Cancer Metastasis Rev 27:5-10

Bodine PV, Komm BS (2006) Wnt signaling and osteoblastogenesis. Rev Endocr Metab Disord 7:33-39

Body JJ, Greipp P, Coleman RE et al (2003) A phase I study of AMGN-0007, a recombinant osteoprotegerin construct, in patients with multiple myeloma or breast carcinoma related bone metastases. Cancer 97:887-892

Bone HG, McClung MR, Roux C et al (2010) Odanacatib, a cathepsin-K inhibitor for osteoporosis: a two-year study in postmenopausal women with low bone density. J Bone Miner Res 25:937-947

Braz JM, Basbaum AI (2010) Differential ATF3 expression in dorsal root ganglion neurons reveals the profile of primary afferents engaged by diverse noxious chemical stimuli. Pain 150:290-301

Brownlow N, Mol C, Hayford C et al (2009) Dasatinib is a potent inhibitor of tumour-associated macrophages, osteoclasts and the FMS receptor. Leukemia 23:590-594

Brubaker KD, Vessella RL, True LD et al (2003) Cathepsin K mRNA and protein expression in prostate cancer progression. $\mathrm{J}$ Bone Miner Res 18:222-230

Buijs JT, Henriquez NV, van Overveld PG et al (2007) TGF-beta and BMP7 interactions in tumour progression and bone metastasis. Clin Exp Metastasis 24:609-617

Bussard KM, Gay CV, Mastro AM (2008) The bone microenvironment in metastasis; what is special about bone? Cancer Metastasis Rev 27:41-55

Campo McKnight DA, Sosnoski DM, Koblinski JE et al (2006) Roles of osteonectin in the migration of breast cancer cells into bone. J Cell Biochem 97:288-302

Carducci MA, Nelson JB, Bowling MK et al (2002) Atrasentan, an endothelin-receptor antagonist for refractory adenocarcinomas: safety and pharmacokinetics. J Clin Oncol 20:2171-2180

Carducci MA, Padley RJ, Breul J et al (2003) Effect of endothelin-A receptor blockade with atrasentan on tumor progression in men with hormone-refractory prostate cancer: a randomized, phase II, placebo-controlled trial. J Clin Oncol 21:679-689

Carducci MA, Saad F, Abrahamsson PA et al (2007) A phase 3 randomized controlled trial of the efficacy and safety of atrasentan in men with metastatic hormone-refractory prostate cancer. Cancer 110:1959-1966

Casimiro S, Guise TA, Chirgwin J (2009) The critical role of the bone microenvironment in cancer metastases. Mol Cell Endocrinol 310:71-81

Castellano D, Sepulveda JM, Garcia-Escobar I et al (2011) The role of RANK-ligand inhibition in cancer: the story of denosumab. Oncologist 16:136-145

Caterina MJ, Leffler A, Malmberg $\mathrm{AB}$ et al (2000) Impaired nociception and pain sensation in mice lacking the capsaicin receptor. Science 288:306-313
Chang YM, Bai L, Liu S et al (2008) Src family kinase oncogenic potential and pathways in prostate cancer as revealed by AZD0530. Oncogene 27:6365-6375

Chen G, Sircar K, Aprikian A et al (2006) Expression of RANKL/ RANK/OPG in primary and metastatic human prostate cancer as markers of disease stage and functional regulation. Cancer 107:289-298

Chirgwin JM, Guise TA (2007) Skeletal metastases: decreasing tumor burden by targeting the bone microenvironment. J Cell Biochem 102:1333-1342

Clare C, Royle D, Saharia K et al (2005) Painful bone metastases: a prospective observational cohort study. Palliat Med 19:521-525

Clarke B (2008) Normal bone anatomy and physiology. Clin J Am Soc Nephrol 3(Suppl 3):S131-S139

Cleary JF (2007) The pharmacologic management of cancer pain. J Palliat Med 10:1369-1394

Clezardin P (2011) Bisphosphonates' antitumor activity: an unravelled side of a multifaceted drug class. Bone 48:71-79

Clines GA, Guise TA (2008) Molecular mechanisms and treatment of bone metastasis. Expert Rev Mol Med 10:e7

Clines GA, Mohammad KS, Bao Y et al (2007) Dickkopf homolog 1 mediates endothelin-1-stimulated new bone formation. Mol Endocrinol 21:486-498

Clohisy DR, O' Keefe PF, Ramnaraine ML (2001) Pamidronate decreases tumor-induced osteoclastogenesis in osteopetrotic mice. J Orthop Res 19:554-558

Clover J, Dodds RA, Gowen M (1992) Integrin subunit expression by human osteoblasts and osteoclasts in situ and in culture. J Cell Sci 103:267-271

Cohen P, Peehl DM, Graves HC et al (1994) Biological effects of prostate specific antigen as an insulin-like growth factor binding protein-3 protease. J Endocrinol 142:407-415

Coleman RE (2006) Clinical features of metastatic bone disease and risk of skeletal morbidity. Clin Cancer Res 12:6243s-6249s

Cramer SD, Chen Z, Peehl DM (1996) Prostate specific antigen cleaves parathyroid hormone-related protein in the PTH-like domain: inactivation of PTHrP-stimulated cAMP accumulation in mouse osteoblasts. J Urol 156:526-531

DaSilva J, Gioeli D, Weber MJ et al (2009) The neuroendocrinederived peptide parathyroid hormone-related protein promotes prostate cancer cell growth by stabilizing the androgen receptor. Cancer Res 69:7402-7411

De Ciantis PD, Yashpal K, Henry J et al (2010) Characterization of a rat model of metastatic prostate cancer bone pain. J Pain Res 3:213-221

Desai B, Rogers MJ, Chellaiah MA (2007) Mechanisms of osteopontin and CD44 as metastatic principles in prostate cancer cells. Mol Cancer 6:18

Dolezal J, Vizda J, Odrazka K (2007) Prospective evaluation of samarium-153-EDTMP radionuclide treatment for bone metastases in patients with hormone-refractory prostate cancer. Urol Int 78:50-57

Donovan-Rodriguez T, Dickenson AH, Urch CE (2004) Superficial dorsal horn neuronal responses and the emergence of behavioural hyperalgesia in a rat model of cancer-induced bone pain. Neurosci Lett 360:29-32

Dougall WC, Glaccum M, Charrier K et al (1999) RANK is essential for osteoclast and lymph node development. Genes Dev 13:2412-2424

Dovio A, Sartori ML, Masera RG et al (2004) Effects of physiological concentrations of steroid hormones and interleukin-11 on basal and stimulated production of interleukin- 8 by human osteoblastlike cells with different functional profiles. Clin Exp Rheumatol 22:79-84 
Eddleston A, Marenzana M, Moore AR et al (2009) A short treatment with an antibody to sclerostin can inhibit bone loss in an ongoing model of colitis. J Bone Miner Res 24:1662-1671

Eisenberg E, Berkey CS, Carr DB et al (1994) Efficacy and safety of nonsteroidal antiinflammatory drugs for cancer pain: a metaanalysis. J Clin Oncol 12:2756-2765

Eisman JA, Bone HG, Hosking DJ et al (2011) Odanacatib in the treatment of postmenopausal women with low bone mineral density: three-year continued therapy and resolution of effect. J Bone Miner Res 26:242-251

Fairchild A, Barnes E, Ghosh S et al (2009) International patterns of practice in palliative radiotherapy for painful bone metastases: evidence-based practice? Int J Radiat Oncol Biol Phys 75:1501-1510

FDA (2010) SPRYCEL ${ }^{\circledR}$ (dasatinib) Tablet. http://www.accessdata. fda.gov/drugsatfda_docs/label/2010/021986s7s8lbl.pdf. Accessed 16 Feb 2013

Feeley BT, Krenek L, Liu N et al (2006) Overexpression of noggin inhibits BMP-mediated growth of osteolytic prostate cancer lesions. Bone 38:154-166

Ferlay J, Shin HR, Bray F et al (2010) Estimates of worldwide burden of cancer in 2008: GLOBOCAN 2008. Int J Cancer 127:2893-2917

Fizazi K, Carducci M, Smith M et al (2011) Denosumab versus zoledronic acid for treatment of bone metastases in men with castration-resistant prostate cancer: a randomised, double-blind study. Lancet 377:813-822

Gordon-Williams RM, Dickenson AH (2007) Central neuronal mechanisms in cancer-induced bone pain. Curr Opin Support Palliat Care 1:6-10

Goyal J, Antonarakis ES (2012) Bone-targeting radiopharmaceuticals for the treatment of prostate cancer with bone metastases. Cancer Lett 323:135-146

Gramoun A, Shorey S, Bashutski JD et al (2007) Effects of vitaxin, a novel therapeutic in trial for metastatic bone tumors, on osteoclast functions in vitro. J Cell Biochem 102:341-352

Guise TA, Chirgwin JM (2003) Transforming growth factor-beta in osteolytic breast cancer bone metastases. Clin Orthop Relat Res 415(Suppl):S32-S38

Guo W, Wang H, Watanabe M et al (2007) Glial-cytokine-neuronal interactions underlying the mechanisms of persistent pain. J Neurosci 27:6006-6018

Hald A, Nedergaard S, Hansen RR et al (2009) Differential activation of spinal cord glial cells in murine models of neuropathic and cancer pain. Eur J Pain 13:138-145

Hall DG, Stoica G (1994) Effect of the bisphosphonate risedronate on bone metastases in a rat mammary adenocarcinoma model system. J Bone Miner Res 9:221-230

Hall CL, Daignault SD, Shah RB et al (2008) Dickkopf-1 expression increases early in prostate cancer development and decreases during progression from primary tumor to metastasis. Prostate 68:1396-1404

Halvorson KG, Kubota K, Sevcik MA et al (2005) A blocking antibody to nerve growth factor attenuates skeletal pain induced by prostate tumor cells growing in bone. Cancer Res 65:9426-9435

Han JH, Choi SJ, Kurihara N et al (2001) Macrophage inflammatory protein-1alpha is an osteoclastogenic factor in myeloma that is independent of receptor activator of nuclear factor kappaB ligand. Blood 97:3349-3353

Han SH, de Klerk JM, Tan S et al (2002) The PLACORHEN study: a double-blind, placebo-controlled, randomized radionuclide study with (186)Re-etidronate in hormone-resistant prostate cancer patients with painful bone metastases. Placebo Controlled Rhenium Study. J Nucl Med 43:1150-1156

Hannon RA, Clack G, Rimmer M et al (2010) Effects of the Src kinase inhibitor saracatinib (AZD0530) on bone turnover in healthy men: a randomized, double-blind, placebo-controlled, multiple-ascending-dose phase I trial. J Bone Miner Res 25:463-471

Hattersley G, Owens J, Flanagan AM et al (1991) Macrophage colony stimulating factor (M-CSF) is essential for osteoclast formation in vitro. Biochem Biophys Res Commun 177:526-531

Hirbe AC, Morgan EA, Weilbaecher KN (2010) The CXCR4/SDF-1 chemokine axis: a potential therapeutic target for bone metastases? Curr Pharm Des 16:1284-1290

Holen I, Croucher PI, Hamdy FC et al (2002) Osteoprotegerin (OPG) is a survival factor for human prostate cancer cells. Cancer Res 62:1619-1623

Honore P, Rogers SD, Schwei MJ et al (2000a) Murine models of inflammatory, neuropathic and cancer pain each generates a unique set of neurochemical changes in the spinal cord and sensory neurons. Neuroscience 98:585-598

Honore P, Schwei J, Rogers SD et al (2000b) Cellular and neurochemical remodeling of the spinal cord in bone cancer pain. Prog Brain Res 129:389-397

Horne WC, Neff L, Chatterjee D et al (1992) Osteoclasts express high levels of pp 60c-src in association with intracellular membranes. J Cell Biol 119:1003-1013

Huang WC, Xie Z, Konaka H et al (2005) Human osteocalcin and bone sialoprotein mediating osteomimicry of prostate cancer cells: role of cAMP-dependent protein kinase A signaling pathway. Cancer Res 65:2303-2313

Hudmon A, Choi JS, Tyrrell L et al (2008) Phosphorylation of sodium channel $\mathrm{Na}(\mathrm{v}) 1.8$ by p38 mitogen-activated protein kinase increases current density in dorsal root ganglion neurons. J Neurosci 28:3190-3201

IASP (2009) Pharmacological management of cancer pain. IASP Press, Seattle

Ibrahim T, Flamini E, Mercatali L et al (2010) Pathogenesis of osteoblastic bone metastases from prostate cancer. Cancer 116:1406-1418

James ND, Caty A, Borre M et al (2009) Safety and efficacy of the specific endothelin-A receptor antagonist ZD4054 in patients with hormone-resistant prostate cancer and bone metastases who were pain free or mildly symptomatic: a double-blind, placebocontrolled, randomised, phase 2 trial. Eur Urol 55:1112-1123

Jemal A, Siegel R, Ward E et al (2007) Cancer statistics, 2007. CA Cancer J Clin 57:43-66

Jensen AB, Wynne C, Ramirez G et al (2010) The cathepsin K inhibitor odanacatib suppresses bone resorption in women with breast cancer and established bone metastases: results of a 4-week, double-blind, randomized, controlled trial. Clin Breast Cancer 10:452-458

Ji RR, Samad TA, Jin SX et al (2002) p38 MAPK activation by NGF in primary sensory neurons after inflammation increases TRPV1 levels and maintains heat hyperalgesia. Neuron 36:57-68

Jimenez-Andrade JM, Bloom AP, Stake JI et al (2010a) Pathological sprouting of adult nociceptors in chronic prostate cancer-induced bone pain. J Neurosci 30:14649-14656

Jimenez-Andrade JM, Mantyh WG, Bloom AP et al (2010b) Bone cancer pain. Ann N Y Acad Sci 1198:173-181

Jimenez-Andrade JM, Ghilardi JR, Castaneda-Corral G et al (2011) Preventive or late administration of anti-NGF therapy attenuates tumor-induced nerve sprouting, neuroma formation, and cancer pain. Pain 152:2564-2574

Jin JK, Dayyani F, Gallick GE (2011) Steps in prostate cancer progression that lead to bone metastasis. Int $\mathrm{J}$ Cancer 128:2545-2561

Jung Y, Wang J, Schneider A et al (2006) Regulation of SDF-1 (CXCL12) production by osteoblasts; a possible mechanism for stem cell homing. Bone 38:497-508

Kakonen SM, Mundy GR (2003) Mechanisms of osteolytic bone metastases in breast carcinoma. Cancer 97:834-839 
Kasperk CH, Borcsok I, Schairer HU et al (1997) Endothelin-1 is a potent regulator of human bone cell metabolism in vitro. Calcif Tissue Int 60:368-374

Khasabov SG, Hamamoto DT, Harding-Rose C et al (2007) Tumorevoked hyperalgesia and sensitization of nociceptive dorsal horn neurons in a murine model of cancer pain. Brain Res 1180:7-19

Kim DS, Figueroa KW, Li KW et al (2009a) Profiling of dynamically changed gene expression in dorsal root ganglia post peripheral nerve injury and a critical role of injury-induced glial fibrillary acidic protein in maintenance of pain behaviors. Pain 143:114-122

Kim LC, Song L, Haura EB (2009b) Src kinases as therapeutic targets for cancer. Nat Rev Clin Oncol 6:587-595

Kingsley LA, Fournier PG, Chirgwin JM et al (2007) Molecular biology of bone metastasis. Mol Cancer Ther 6:2609-2617

Knox JD, Cress AE, Clark V et al (1994) Differential expression of extracellular matrix molecules and the alpha 6-integrins in the normal and neoplastic prostate. Am J Pathol 145:167-174

Kohno T, Moore KA, Baba $\mathrm{H}$ et al (2003) Peripheral nerve injury alters excitatory synaptic transmission in lamina II of the rat dorsal horn. J Physiol 548:131-138

Kolosov A, Aurini L, Williams ED et al (2011) Intravenous injection of leconotide, an omega conotoxin: synergistic antihyperalgesic effects with morphine in a rat model of bone cancer pain. Pain Med 12:923-941

Koreckij T, Nguyen H, Brown LG et al (2009) Dasatinib inhibits the growth of prostate cancer in bone and provides additional protection from osteolysis. Br J Cancer 101:263-268

Kozlow W, Guise TA (2005) Breast cancer metastasis to bone: mechanisms of osteolysis and implications for therapy. J Mammary Gland Biol Neoplasia 10:169-180

Kryger GS, Kryger Z, Zhang F et al (2001) Nerve growth factor inhibition prevents traumatic neuroma formation in the rat. J Hand Surg Am 26:635-644

Kundu N, Yang Q, Dorsey R et al (2001) Increased cyclooxygenase-2 (cox-2) expression and activity in a murine model of metastatic breast cancer. Int J Cancer 93:681-686

Kwan Tat S, Padrines M, Theoleyre S et al (2004) IL-6, RANKL, TNF-alpha/IL-1: interrelations in bone resorption pathophysiology. Cytokine Growth Factor Rev 15:49-60

Lacey DL, Timms E, Tan HL et al (1998) Osteoprotegerin ligand is a cytokine that regulates osteoclast differentiation and activation. Cell 93:165-176

Laird JM, Bennett GJ (1993) An electrophysiological study of dorsal horn neurons in the spinal cord of rats with an experimental peripheral neuropathy. J Neurophysiol 69:2072-2085

Lalich M, McNeel DG, Wilding G et al (2007) Endothelin receptor antagonists in cancer therapy. Cancer Invest 25:785-794

Lam MG, Dahmane A, Stevens WHBA et al (2008) Combined use of zoledronic acid and 153Sm-EDTMP in hormone-refractory prostate cancer patients with bone metastases. Eur J Nucl Med Mol Imaging 35:756-765

Lambert B, de Klerk JM (2006) Clinical applications of 188Relabelled radiopharmaceuticals for radionuclide therapy. Nucl Med Commun 27:223-229

Lamoureux F, Ory B, Battaglia S et al (2008) Relevance of a new rat model of osteoblastic metastases from prostate carcinoma for preclinical studies using zoledronic acid. Int $\mathrm{J}$ Cancer 122:751-760

Lara PN Jr, Longmate J, Evans CP et al (2009) A phase II trial of the Src-kinase inhibitor AZD0530 in patients with advanced castration-resistant prostate cancer: a California Cancer Consortium study. Anticancer Drugs 20:179-184

Latremoliere A, Woolf CJ (2009) Central sensitization: a generator of pain hypersensitivity by central neural plasticity. J Pain 10:895-926
Lee LF, Guan J, Qiu Y et al (2001) Neuropeptide-induced androgen independence in prostate cancer cells: roles of nonreceptor tyrosine kinases Etk/Bmx, Src, and focal adhesion kinase. Mol Cell Biol 21:8385-8397

Lee LF, Louie MC, Desai SJ et al (2004) Interleukin-8 confers androgen-independent growth and migration of LNCaP: differential effects of tyrosine kinases Src and FAK. Oncogene 23:2197-2205

Lee RJ, Saylor PJ, Smith MR (2011) Treatment and prevention of bone complications from prostate cancer. Bone 48:88-95

Leeming DJ, Hegele A, Byrjalsen I et al (2008) Biochemical markers for monitoring response to therapy: evidence for higher bone specificity by a novel marker compared with routine markers. Cancer Epidemiol Biomarkers Prev 17:1269-1276

Lemke M, Liena K, Zenga L et al (2012) New considerations in the design of clinical trials for bone metastases. World J Oncol 3:1-7

Lewiecki EM (2011) Sclerostin monoclonal antibody therapy with AMG 785: a potential treatment for osteoporosis. Expert Opin Biol Ther 11:117-127

Lewington VJ (1996) Cancer therapy using bone-seeking isotopes. Phys Med Biol 41:2027-2042

Lewington VJ, McEwan AJ, Ackery DM et al (1991) A prospective, randomised double-blind crossover study to examine the efficacy of strontium-89 in pain palliation in patients with advanced prostate cancer metastatic to bone. Eur J Cancer 27:954-958

Li J, Sarosi I, Yan XQ et al (2000) RANK is the intrinsic hematopoietic cell surface receptor that controls osteoclastogenesis and regulation of bone mass and calcium metabolism. Proc Natl Acad Sci USA 97:1566-1571

Li X, Ominsky MS, Niu QT et al (2008) Targeted deletion of the sclerostin gene in mice results in increased bone formation and bone strength. J Bone Miner Res 23:860-869

Li X, Ominsky MS, Warmington KS et al (2009) Sclerostin antibody treatment increases bone formation, bone mass, and bone strength in a rat model of postmenopausal osteoporosis. J Bone Miner Res 24:578-588

Liepe K, Kotzerke J (2007) A comparative study of 188Re-HEDP, 186Re-HEDP, 153Sm-EDTMP and 89Sr in the treatment of painful skeletal metastases. Nucl Med Commun 28:623-630

Liepe K, Geidel H, Haase M et al (2005) New model for the induction of osteoblastic bone metastases in rat. Anticancer Res 25:1067-1073

Lilleby W (2007) Use of bisphosphonates in advanced prostate cancer: current status. Indian J Urol 23:54

Lin A, Ray ME (2006) Targeted and systemic radiotherapy in the treatment of bone metastasis. Cancer Metastasis Rev 25:669-675

Lin T, Li K, Zhang FY et al (2007) Dissociation of spinal microglia morphological activation and peripheral inflammation in inflammatory pain models. J Neuroimmunol 192:40-48

Lin C, Jiang X, Dai Z et al (2009) Sclerostin mediates bone response to mechanical unloading through antagonizing Wnt/beta-catenin signaling. J Bone Miner Res 24:1651-1661

Lipton A (2007) Treatment of bone metastases and bone pain with bisphosphonates. Support Cancer Ther 4:92-100

Lipton A (2010) Bone continuum of cancer. Am J Clin Oncol 33:S1-S7

Lipton A, Goessl C (2011) Clinical development of anti-RANKL therapies for treatment and prevention of bone metastasis. Bone 48:96-99

Littlewood-Evans AJ, Bilbe G, Bowler WB et al (1997) The osteoclast-associated protease cathepsin $\mathrm{K}$ is expressed in human breast carcinoma. Cancer Res 57:5386-5390

Liu FY, Qu XX, Cai J et al (2011) Electrophysiological properties of spinal wide dynamic range neurons in neuropathic pain rats following spinal nerve ligation. Neurosci Bull 27:1-8

Lu Y, Chen Q, Corey E et al (2009) Activation of MCP-1/CCR2 axis promotes prostate cancer growth in bone. Clin Exp Metastasis 26:161-169 
Luo Y, Zhang LL, Ning L et al (2006) Establishment of bone metastasis model of prostate cancer in nude mice by intratibia injection of human prostate cancer cell line Du145. Zhonghua Nan Ke Xue 12:133-136

Luzzi KJ, MacDonald IC, Schmidt EE et al (1998) Multistep nature of metastatic inefficiency: dormancy of solitary cells after successful extravasation and limited survival of early micrometastases. Am J Pathol 153:865-873

Manas A, Casas F, Ciria JP et al (2008) Randomised study of single dose (8 Gy vs. $6 \mathrm{~Gy}$ ) of analgesic radiotherapy plus zoledronic acid in patients with bone metastases. Clin Transl Oncol 10:281-287

Mantyh PW (2006) Cancer pain and its impact on diagnosis, survival and quality of life. Nat Rev Neurosci 7:797-809

Mantyh PW, Koltzenburg M, Mendell LM et al (2011) Antagonism of nerve growth factor-TrkA signaling and the relief of pain. Anesthesiology 115:189-204

Marenzana M, Greenslade K, Eddleston A et al (2011) Sclerostin antibody treatment enhances bone strength but does not prevent growth retardation in young mice treated with dexamethasone. Arthritis Rheum 63:2385-2395

Martin SW, Butcher AJ, Berrow NS et al (2006) Phosphorylation sites on calcium channel alpha1 and beta subunits regulate ERKdependent modulation of neuronal N-type calcium channels. Cell Calcium 39:275-292

Martin CD, Jimenez-Andrade JM, Ghilardi JR et al (2007) Organization of a unique net-like meshwork of CGRP + sensory fibers in the mouse periosteum: implications for the generation and maintenance of bone fracture pain. Neurosci Lett 427:148-152

McNicol E, Strassels SA, Goudas L et al (2005) NSAIDS or paracetamol, alone or combined with opioids, for cancer pain. Cochrane Database Syst Rev 25:CD005180

McQuay HJ, Collins SL, Carroll D et al (2000) Radiotherapy for the palliation of painful bone metastases. Cochrane Database Syst Rev 2:CD001793

Mercadante S (1997) Malignant bone pain: pathophysiology and treatment. Pain 69:1-18

Mercadante S, Arcuri E (1998) Breakthrough pain in cancer patients: pathophysiology and treatment. Cancer Treat Rev 24:425-432

Mercadante S, Fulfaro F (2007) Management of painful bone metastases. Curr Opin Oncol 19:308-314

Millard M, Odde S, Neamati N (2011) Integrin targeted therapeutics. Theranostics 1:154-188

Moester MJ, Papapoulos SE, Lowik CW et al (2010) Sclerostin: current knowledge and future perspectives. Calcif Tissue Int 87:99-107

Mohammad KS, Guise TA (2003) Mechanisms of osteoblastic metastases: role of endothelin-1. Clin Orthop Relat Res 415:S67-S74

Morrissey C, Vessella RL (2007) The role of tumor microenvironment in prostate cancer bone metastasis. J Cell Biochem 101:873-886

Msaouel P, Pissimissis N, Halapas A et al (2008) Mechanisms of bone metastasis in prostate cancer: clinical implications. Best Pract Res Clin Endocrinol Metab 22:341-355

Mundy GR, Chen D, Zhao M et al (2001) Growth regulatory factors and bone. Rev Endocr Metab Disord 2:105-115

Muralidharan A, Wyse BD, Smith MT (2013) Optimization and characterization of a rat model of prostate cancer-induced bone pain using behavioural, pharmacological, radiological, histological and immunohistochemical methods. Pharmacol Biochem Behav 106:33-46

Naing A, Cohen R, Dy GK et al (2013) A phase I trial of KX2-391, a novel non-ATP competitive substrate-pocket- directed SRC inhibitor, in patients with advanced malignancies. Invest New Drugs. doi:10.1007/s10637-013-9929-8
Nakamura I, le Duong T, Rodan SB et al (2007) Involvement of alpha(v)beta3 integrins in osteoclast function. J Bone Miner Metab 25:337-344

Nam S, Kim D, Cheng JQ et al (2005) Action of the Src family kinase inhibitor, dasatinib (BMS-354825), on human prostate cancer cells. Cancer Res 65:9185-9189

Nelson JB, Hedican SP, George DJ et al (1995) Identification of endothelin-1 in the pathophysiology of metastatic adenocarcinoma of the prostate. Nat Med 1:944-949

Nelson JB, Nabulsi AA, Vogelzang NJ et al (2003) Suppression of prostate cancer induced bone remodeling by the endothelin receptor A antagonist atrasentan. J Urol 169:1143-1149

Nelson JB, Love W, Chin JL, Saad F, Schulman CC, Sleep DJ, Qian J, Steinberg J, Carducci M (2008) Phase 3, randomized, controlled trial of atrasentan in patients with nonmetastatic, hormone-refractory prostate cancer. Cancer 113:2478-2487

Nersesyan H, Slavin KV (2007) Current approach to cancer pain management: availability and implications of different treatment options. Ther Clin Risk Manag 3:381-400

Neville-Webbe HL, Cross NA, Eaton CL et al (2004) Osteoprotegerin (OPG) produced by bone marrow stromal cells protects breast cancer cells from TRAIL-induced apoptosis. Breast Cancer Res Treat 86:269-279

Nilsson S, Strang P, Aksnes AK et al (2012) A randomized, doseresponse, multicenter phase II study of radium-223 chloride for the palliation of painful bone metastases in patients with castration-resistant prostate cancer. Eur J Cancer 48:678-686

Nilsson S, Sartor O, Oyvind S et al (2013) Pain analysis from the phase III randomized ALSYMPCA study with radium-223 dichloride (Ra-223) in patients with castration-resistant prostate cancer (CRPC) with bone metastases. J Clin Oncol 31(Suppl 6): 19

Nomiya T, Teruyama K, Wada $\mathrm{H}$ et al (2010) Time course of pain relief in patients treated with radiotherapy for cancer pain: a prospective study. Clin J Pain 26:38-42

Okamoto M, Baba H, Goldstein PA et al (2001) Functional reorganization of sensory pathways in the rat spinal dorsal horn following peripheral nerve injury. J Physiol 532:241-250

Olson TH, Riedl MS, Vulchanova L et al (1998) An acid sensing ion channel (ASIC) localizes to small primary afferent neurons in rats. NeuroReport 9:1109-1113

Oosterhof GO, Roberts JT, de Reijke TM et al (2003) Strontium(89) chloride versus palliative local field radiotherapy in patients with hormonal escaped prostate cancer: a phase III study of the European Organisation for Research and Treatment of Cancer, Genitourinary Group. Eur Urol 44:519-526

Opgenorth TJ, Adler AL, Calzadilla SV et al (1996) Pharmacological characterization of A-127722: an orally active and highly potent ETA-selective receptor antagonist. J Pharmacol Exp Ther 276:473-481

Pagliaro LC, Delpassand ES, Williams D et al (2003) A Phase I/II study of strontium-89 combined with gemcitabine in the treatment of patients with androgen independent prostate carcinoma and bone metastases. Cancer 97:2988-2994

Pandit-Taskar N, Batraki M, Divgi CR (2004) Radiopharmaceutical therapy for palliation of bone pain from osseous metastases. J Nucl Med 45:1358-1365

Park SI, Zhang J, Phillips KA et al (2008) Targeting SRC family kinases inhibits growth and lymph node metastases of prostate cancer in an orthotopic nude mouse model. Cancer Res 68:3323-3333

Parker C, Heinrich D, O'Sullivan JM et al (2012) Overall survival benefit and safety profile of radium-223 chloride, a first-in-class alpha-pharmaceutical: results from a phase III randomized trial (ALSYMPCA) in patients with castration-resistant prostate cancer (CRPC) with bone metastases. J Clin Oncol 30(Suppl 5):8 
Parker CC, Pascoe S, Chodacki A et al (2013) A randomized, doubleblind, dose-finding, multicenter, phase 2 study of radium chloride ( $\mathrm{Ra} 223$ ) in patients with bone metastases and castration-resistant prostate cancer. Eur Urol 63:189-197

Peleshok JC, Ribeiro-da-Silva A (2011) Delayed reinnervation by nonpeptidergic nociceptive afferents of the glabrous skin of the rat hindpaw in a neuropathic pain model. J Comp Neurol 519:49-63

Peters CM, Ghilardi JR, Keyser CP et al (2005) Tumor-induced injury of primary afferent sensory nerve fibers in bone cancer pain. Exp Neurol 193:85-100

Porter AT, McEwan AJ, Powe JE et al (1993) Results of a randomized phase-III trial to evaluate the efficacy of strontium- 89 adjuvant to local field external beam irradiation in the management of endocrine resistant metastatic prostate cancer. Int J Radiat Oncol Biol Phys 25:805-813

Pratap J, Lian JB, Stein GS (2011) Metastatic bone disease: role of transcription factors and future targets. Bone 48:30-36

Proff P, Romer P (2009) The molecular mechanism behind bone remodelling: a review. Clin Oral Investig 13:355-362

Quilty PM, Kirk D, Bolger JJ et al (1994) A comparison of the palliative effects of strontium- 89 and external beam radiotherapy in metastatic prostate cancer. Radiother Oncol 31:33-40

Rachner TD, Hadji P, Hofbauer LC (2012) Novel therapies in benign and malignant bone diseases. Pharmacol Ther 134:338-344

Rades D, Schild SE, Abrahm JL (2010) Treatment of painful bone metastases. Nat Rev Clin Oncol 7:220-229

Raghavendra V, Tanga FY, DeLeo JA (2004) Complete Freunds adjuvant-induced peripheral inflammation evokes glial activation and proinflammatory cytokine expression in the CNS. Eur $\mathrm{J}$ Neurosci 20:467-473

Rainville P, Duncan GH, Price DD et al (1997) Pain affect encoded in human anterior cingulate but not somatosensory cortex. Science 277:968-971

Resche I, Chatal JF, Pecking A et al (1997) A dose-controlled study of 153Sm-ethylenediaminetetramethylenephosphonate (EDTMP) in the treatment of patients with painful bone metastases. Eur J Cancer 33:1583-1591

Robinson RG, Preston DF, Baxter KG et al (1993) Clinical experience with strontium- 89 in prostatic and breast cancer patients. Semin Oncol 20:44-48

Robinson DR, Zylstra CR, Williams BO (2008) Wnt signaling and prostate cancer. Curr Drug Targets 9:571-580

Rodrigues P, Hering F, Campagnari JC (2004) Use of bisphosphonates can dramatically improve pain in advanced hormonerefractory prostate cancer patients. Prostate Cancer Prostatic Dis $7: 350-354$

Roodman GD (2001) Biology of osteoclast activation in cancer. J Clin Oncol 19:3562-3571

Roque IFM, Martinez-Zapata MJ, Scott-Brown M et al (2011) Radioisotopes for metastatic bone pain. Cochrane Database Syst Rev 7:CD003347

Rosenthal MA, Davidson P, Rolland F et al (2010) Evaluation of the safety, pharmacokinetics and treatment effects of an alpha(nu)beta(3) integrin inhibitor on bone turnover and disease activity in men with hormone-refractory prostate cancer and bone metastases. Asia Pac J Clin Oncol 6:42-48

Roudier MP, Haynes K, Feldman R et al (2005) Evaluation of pain in breast and prostate cancer bone metastasis rat models. AACR Meeting Abstracts 2005:684

Ruiz G, Ceballos D, Banos JE (2004) Behavioral and histological effects of endoneurial administration of nerve growth factor: possible implications in neuropathic pain. Brain Res 1011:1-6

Russell RG, Rogers MJ, Frith JC et al (1999) The pharmacology of bisphosphonates and new insights into their mechanisms of action. J Bone Miner Res 14:53-65
Russo A, Bronte G, Rizzo S et al (2010) Anti-endothelin drugs in solid tumors. Expert Opin Emerg Drugs 15:27-40

Ryan CW, Vogelzang NJ, Vokes EE et al (2004) Dose-ranging study of the safety and pharmacokinetics of atrasentan in patients with refractory malignancies. Clin Cancer Res 10:4406-4411

Saad F, Lipton A (2010a) Bone-marker levels in patients with prostate cancer: potential correlations with outcomes. Curr Opin Support Palliat Care 4:127-134

Saad F, Lipton A (2010b) SRC kinase inhibition: targeting bone metastases and tumor growth in prostate and breast cancer. Cancer Treat Rev 36:177-184

Saad F, Gleason DM, Murray R et al (2002) A randomized, placebocontrolled trial of zoledronic acid in patients with hormonerefractory metastatic prostate carcinoma. J Natl Cancer Inst 94:1458-1468

Saad F, Gleason DM, Murray R et al (2004) Long-term efficacy of zoledronic acid for the prevention of skeletal complications in patients with metastatic hormone-refractory prostate cancer. J Natl Cancer Inst 96:879-882

Sabino MA, Ghilardi JR, Jongen JL et al (2002) Simultaneous reduction in cancer pain, bone destruction, and tumor growth by selective inhibition of cyclooxygenase-2. Cancer Res 62:7343-7349

Saftig P, Hunziker E, Wehmeyer O et al (1998) Impaired osteoclastic bone resorption leads to osteopetrosis in cathepsin-K-deficient mice. Proc Natl Acad Sci USA 95:13453-13458

Sartor O, Reid RH, Hoskin PJ et al (2004) Samarium-153-lexidronam complex for treatment of painful bone metastases in hormonerefractory prostate cancer. Urology 63:940-945

Saylor PJ, Smith MR (2010) Bone health and prostate cancer. Prostate Cancer Prostatic Dis 13:20-27

Saylor PJ, Armstrong AJ, Fizazi K et al (2013) New and emerging therapies for bone metastases in genitourinary cancers. Eur Urol 63:309-320

Schelman WR, Liu G, Wilding G et al (2011) A phase I study of zibotentan (ZD4054) in patients with metastatic, castrate-resistant prostate cancer. Invest New Drugs 29:118-125

Schluter KD, Katzer C, Piper HM (2001) A N-terminal PTHrP peptide fragment void of a PTH/PTHrP-receptor binding domain activates cardiac ET(A) receptors. Br J Pharmacol 132:427-432

Schmidt BL, Hamamoto DT, Simone DA et al (2010) Mechanism of cancer pain. Mol Interv 10:164-178

Schneider JG, Amend SR, Weilbaecher KN (2011) Integrins and bone metastasis: integrating tumor cell and stromal cell interactions. Bone 48:54-65

Scholz J, Broom DC, Youn DH et al (2005) Blocking caspase activity prevents transsynaptic neuronal apoptosis and the loss of inhibition in lamina II of the dorsal horn after peripheral nerve injury. J Neurosci 25:7317-7323

Schwarz EM, Ritchlin CT (2007) Clinical development of antiRANKL therapy. Arthritis Res Ther 9:S7

Schwei MJ, Honore P, Rogers SD et al (1999) Neurochemical and cellular reorganization of the spinal cord in a murine model of bone cancer pain. J Neurosci 19:10886-10897

Sciuto R, Festa A, Rea S et al (2002) Effects of low-dose cisplatin on 89Sr therapy for painful bone metastases from prostate cancer: a randomized clinical trial. J Nucl Med 43:79-86

Seftor RE, Seftor EA, Gehlsen KR et al (1992) Role of the alpha v beta 3 integrin in human melanoma cell invasion. Proc Natl Acad Sci USA 89:1557-1561

Seibel MJ (2008) The use of molecular markers of bone turnover in the management of patients with metastatic bone disease. Clin Endocrinol (Oxf) 68:839-849

Serafini AN, Houston SJ, Resche I et al (1998) Palliation of pain associated with metastatic bone cancer using samarium-153 lexidronam: a double-blind placebo-controlled clinical trial. J Clin Oncol 16:1574-1581 
Sethi N, Kang Y (2011) Dysregulation of developmental pathways in bone metastasis. Bone 48:16-22

Sherrington CS (1906) The integrative action of the nervous system. Scribner, New York

Simone DA, Khasabov SG, Hamamoto DT (2008) Changes in response properties of nociceptive dorsal horn neurons in a murine model of cancer pain. Sheng Li Xue Bao 60:635-644

Small EJ, Smith MR, Seaman JJ et al (2003) Combined analysis of two multicenter, randomized, placebo-controlled studies of pamidronate disodium for the palliation of bone pain in men with metastatic prostate cancer. J Clin Oncol 21:4277-4284

Smeland S, Erikstein B, Aas M et al (2003) Role of strontium-89 as adjuvant to palliative external beam radiotherapy is questionable: results of a double-blind randomized study. Int J Radiat Oncol Biol Phys 56:1397-1404

Smith MT, Muralidharan A (2013) Pain pharmacology and the pharmacological management of pain. In: Unruh AM, Strong J, Baxter GD (eds) Pain: a textbook for health professionals, chap 11, 2nd edn. Churchill Livingstone, London (in press)

Sommer C, Lalonde A, Heckman HM et al (1995) Quantitative neuropathology of a focal nerve injury causing hyperalgesia. J Neuropathol Exp Neurol 54:635-643

Sotgiu ML, Biella G, Riva L (1994) A study of early ongoing activity in dorsal horn units following sciatic nerve constriction. NeuroReport 5:2609-2612

Sotgiu ML, Biella G, Riva L (1995) Poststimulus afterdischarges of spinal WDR and NS units in rats with chronic nerve constriction. NeuroReport 6:1021-1024

Stamboulian S, Choi JS, Ahn HS et al (2010) ERK1/2 mitogen-activated protein kinase phosphorylates sodium channel $\mathrm{Na}(\mathrm{v}) 1.7$ and alters its gating properties. J Neurosci 30:1637-1647

Stoch SA, Zajic S, Stone J et al (2009) Effect of the cathepsin K inhibitor odanacatib on bone resorption biomarkers in healthy postmenopausal women: two double-blind, randomized, placebo-controlled phase I studies. Clin Pharmacol Ther 86:175-182

Sumitani K, Kamijo R, Toyoshima T et al (2001) Specific inhibition of cyclooxygenase-2 results in inhibition of proliferation of oral cancer cell lines via suppression of prostaglandin E2 production. J Oral Pathol Med 30:41-47

Summy JM, Gallick GE (2003) Src family kinases in tumor progression and metastasis. Cancer Metastasis Rev 22:337-358

Sun YX, Wang J, Shelburne CE et al (2003) Expression of CXCR4 and CXCL12 (SDF-1) in human prostate cancers (PCa) in vivo. J Cell Biochem 89:462-473

Sun YX, Schneider A, Jung Y et al (2005) Skeletal localization and neutralization of the SDF-1(CXCL12)/CXCR4 axis blocks prostate cancer metastasis and growth in osseous sites in vivo. J Bone Miner Res 20:318-329

Suzuki R, Kontinen VK, Matthews E et al (2000) Enlargement of the receptive field size to low intensity mechanical stimulation in the rat spinal nerve ligation model of neuropathy. Exp Neurol 163:408-413

Sze WM, Shelley MD, Held I et al (2003) Palliation of metastatic bone pain: single fraction versus multifraction radiotherapy-a systematic review of randomised trials. Clin Oncol (R Coll Radiol) 15:345-352

Sze WM, Shelley M, Held I et al (2004) Palliation of metastatic bone pain: single fraction versus multifraction radiotherapy-a systematic review of the randomised trials. Cochrane Database Syst Rev 2:CD004721

Taichman RS, Cooper C, Keller ET et al (2002) Use of the stromal cell-derived factor-1/CXCR4 pathway in prostate cancer metastasis to bone. Cancer Res 62:1832-1837

Takahashi N, Udagawa N, Takami M et al (2002) Cells of bone: osteoclast generation. Principles of bone biology, vol 1st. Academic, San Diego
Teicher BA, Fricker SP (2010) CXCL12 (SDF-1)/CXCR4 pathway in cancer. Clin Cancer Res 16:2927-2931

Tian X, Setterberg RB, Li X et al (2010) Treatment with a sclerostin antibody increases cancellous bone formation and bone mass regardless of marrow composition in adult female rats. Bone 47:529-533

Tong D, Gillick L, Hendrickson FR (1982) The palliation of symptomatic osseous metastases: final results of the Study by the Radiation Therapy Oncology Group. Cancer 50:893-899

Trump DL, Payne H, Miller K et al (2011) Preliminary study of the specific endothelin a receptor antagonist zibotentan in combination with docetaxel in patients with metastatic castrationresistant prostate cancer. Prostate 71:1264-1275

Tu SM, Lin SH (2008) Current trials using bone-targeting agents in prostate cancer. Cancer J 14:35-39

Urch CE, Donovan-Rodriguez T, Dickenson AH (2003) Alterations in dorsal horn neurones in a rat model of cancer-induced bone pain. Pain 106:347-356

Vallejo R, Tilley DM, Vogel L et al (2010) The role of glia and the immune system in the development and maintenance of neuropathic pain. Pain Pract 10:167-184

van der Pluijm G, Sijmons B, Vloedgraven H et al (2001) Monitoring metastatic behavior of human tumor cells in mice with speciesspecific polymerase chain reaction: elevated expression of angiogenesis and bone resorption stimulators by breast cancer in bone metastases. J Bone Miner Res 16:1077-1091

Vandyke K, Dewar AL, Farrugia AN et al (2009) Therapeutic concentrations of dasatinib inhibit in vitro osteoclastogenesis. Leukemia 23:994-997

Vogel CL, Yanagihara RH, Wood AJ et al (2004) Safety and pain palliation of zoledronic acid in patients with breast cancer, prostate cancer, or multiple myeloma who previously received bisphosphonate therapy. Oncologist 9:687-695

Walz DA, Fenton JW (1994) The role of thrombin in tumor cell metastasis. Invasion Metastasis 14:303-308

Weilbaecher KN, Guise TA, McCauley LK (2011) Cancer to bone: a fatal attraction. Nat Rev Cancer 11:411-425

WHO (1986) Cancer pain relief. WHO, Geneva

Wilson SR, Peters C, Saftig P et al (2009) Cathepsin K activitydependent regulation of osteoclast actin ring formation and bone resorption. J Biol Chem 284:2584-2592

Wong R, Wiffen PJ (2002) Bisphosphonates for the relief of pain secondary to bone metastases. Cochrane Database Syst Rev 2:CD002068

Wu JS, Wong R, Johnston M et al (2003) Meta-analysis of dosefractionation radiotherapy trials for the palliation of painful bone metastases. Int J Radiat Oncol Biol Phys 55:594-605

Wu JD, Higgins LM, Steinle A et al (2004) Prevalent expression of the immunostimulatory MHC class I chain-related molecule is counteracted by shedding in prostate cancer. J Clin Invest 114:560-568

Yanagisawa Y, Furue H, Kawamata T et al (2010) Bone cancer induces a unique central sensitization through synaptic changes in a wide area of the spinal cord. Mol Pain 6:38

Ye L, Kynaston HG, Jiang WG (2007) Bone metastasis in prostate cancer: molecular and cellular mechanisms (review). Int J Mol Med 20:103-111

Yen LD, Bennett GJ, Ribeiro-da-Silva A (2006) Sympathetic sprouting and changes in nociceptive sensory innervation in the glabrous skin of the rat hind paw following partial peripheral nerve injury. J Comp Neurol 495:679-690

Yi B, Williams PJ, Niewolna M et al (2002) Tumor-derived plateletderived growth factor-BB plays a critical role in osteosclerotic bone metastasis in an animal model of human breast cancer. Cancer Res 62:917-923

Yoneda T, Sasaki A, Dunstan C et al (1997) Inhibition of osteolytic bone metastasis of breast cancer by combined treatment with the 
bisphosphonate ibandronate and tissue inhibitor of the matrix metalloproteinase-2. J Clin Invest 99:2509-2517

Yu E, Wilding G, Posadas E et al (2009) Phase II Study of dasatinib in patients with metastatic castration-resistant prostate cancer. Clin Cancer Res 15:7421-7428

Yu E, Massard C, Gross ME et al (2011) Once-daily dasatinib: expansion of phase II study evaluating safety and efficacy of dasatinib in patients with metastatic castration-resistant prostate cancer. Urology 77:1166-1171

Yuen KK, Shelley M, Sze WM et al (2006) Bisphosphonates for advanced prostate cancer. Cochrane Database Syst Rev 4:CD006250

Zhang JM, Strong JA (2008) Recent evidence for activity-dependent initiation of sympathetic sprouting and neuropathic pain. Sheng Li Xue Bao 60:617-627
Zhang RX, Liu B, Wang L et al (2005) Spinal glial activation in a new rat model of bone cancer pain produced by prostate cancer cell inoculation of the tibia. Pain 118:125-136

Zhang RX, Liu B, Li A et al (2008a) Interleukin 1beta facilitates bone cancer pain in rats by enhancing NMDA receptor NR-1 subunit phosphorylation. Neuroscience 154:1533-1538

Zhang S, Qi L, Li M et al (2008b) Chemokine CXCL12 and its receptor CXCR4 expression are associated with perineural invasion of prostate cancer. J Exp Clin Cancer Res 27:62

Zhang Y, Ma B, Fan Q (2010) Mechanisms of breast cancer bone metastasis. Cancer Lett 292:1-7

Zonnenberg BA, Groenewegen G, Janus TJ et al (2003) Phase I doseescalation study of the safety and pharmacokinetics of atrasentan: an endothelin receptor antagonist for refractory prostate cancer. Clin Cancer Res 9:2965-2972 